\title{
IMPORTANCE OF ETHICAL COMPETENCE FOR THE SALES MANAGEMENT OF SMALL AND MEDIUM-SIZED FINANCIAL SALES ORGANIZATIONS
}

\section{Christian ENZa, Dagmar ŠKODOVÁ PARMOVÁa, Paul WOLF}

\author{
${ }^{\text {a }}$ Faculty of Economics, University of South Bohemia Studentská 1337005 České Budějovice, Czech \\ Republic, enzchr00@jcu.cz; parmova@ef.jcu.cz \\ ${ }^{b}$ Mathematics and Statistics, University of Stralsund, Zur Schwedenschanze 15, 18435 Stralsund, \\ Germany,paul.wolf@hochschule-stralsund.de
}

Cite this article: Enz, C. Škodová Parmová, D., Wolf, P. (2021). Importance of ethical competence for the sales management of small and medium-sized financial sales organizations. Deturope. 13(1), 121-152.

\begin{abstract}
For a long time, companies in the financial sector and their management were measured exclusively in terms of business success. However, the public debate on issues such as equality, diversity, inclusion, and sustainability has now also reached the financial sector.

At the same time, brands are increasingly being asked to demonstrate their attitude. Financial service providers are increasingly meeting this demand. However, the distribution of financial and insurance products in Germany is largely carried out by commercially independent small and medium-sized distribution partners.

This research project aims to identify the significance of the career building block 'ethical competence' for a career in financial services sales. Within the framework of a qualitative content analysis, 50 Germanlanguage university study programs in the field of "sales management" are examined. The consideration of ethical aspects in the curriculum is investigated. In a second step, a large-scale survey of sales managers will be conducted. This will determine the extent to which the study programs meet the expectations of practice regarding business ethics.
\end{abstract}

Keywords: Sales management, Business ethics, Insurance, Finance service, SME

\section{INTRODUCTION}

The economic and social environment in which companies operate today is increasingly characterized by complexity, dynamism and ultimately competition (Škodová Parmová, Líšková, Sdrolias, \& Kain, 2017). This development observed by Parmová, Lišková and Kain (2018) in almost every industry (Škodová Parmová, Lišková, \& Kain, 2018) no longer leads solely to the lively competition called for by Meyer (2020), which produces innovations and improved offerings (Meyer, 2020, p. 27). Enz \& Škodová Parmová (2020), for example, attest that various industries are now facing persistent, destructive competition, which is leading to increasing market concentration (Enz \& Škodová Parmová, 2020, p. 141). An example of this is the German financial sector. There, the number of insurance companies has decreased from 
939 companies in 1960 to 530 institutions in 2019 (Hohenstein, 2020, 16 ff). The number of credit institutions in Germany has also declined sharply. According to the German Bundesbank, it fell from 13,359 banks and savings banks in 1957 to 1,717 financial institutions in 2019 (Deutsche Bundesbank, 2020). For a long time, this led to a successdriven corporate policy. According to Blatter (2003), increasing returns or above-average growth were the decisive factors for financial service providers who wanted to maintain their position on the market in the long term (Blattner, 2003, p. 377). Behind this is the idea of achieving success and prosperity with infinitely increasing economic growth. An approach that is pursued by almost all governments worldwide today (Chesney, Krakow, MaranghinoSinger, \& Münstermann, 2018, p. 206). Considering dwindling raw materials, advancing climate change and refugee crises triggered by unacceptable living conditions, Elodi et al. (2020) and Kašparová and Vejsadová Dryjová (2021) recognize increasing interest in change. Sustainable and ethical management concepts are emerging and gaining importance (Elodie, Absi, \& Borodin, 2020; Kašparová \& Vejsadová Dryjová, 2021, p. 134). In other words: Sustainable thinking is inextricably linked to economic development. This is because customers increasingly expect the interests of future generations to be considered in addition to the satisfaction of current needs (Krechovska \& Hejdukova, 2019, p. 20). This means that a development is now continuing in general management that Fabisch (2017) previously identified in human resource management. It was already apparent in the mid-2010s that ethically correct handling of personnel represents a competitive advantage in the recruitment of new employees (Fabisch, 2017, p. 10).

Compared to the Anglo-Saxon economic area, the importance of ethical aspects developed very slowly in Germany. Loew et al. (2004) see the reason for this in a strongly developed welfare state. For a long time, the business community saw the state alone as responsible for issues of general welfare. This was justified by high taxes and contributions in international comparison (Loew, Ankele, Braun, \& Clausen, 2004, p. 79). In addition, according to Enkelmann \& Pridatt (2014), business ethics is not part of the economic canon, but is assigned to philosophy (Enkelmann \& Priddat, 2014). In contrast, business ethics is implicitly considered part of the plural economy in current economic models (Pridatt, 2018; Priddat, 2020 , p. 14). A development that is now strongly driven by consumers. For example, 90 percent of the members of the organization „Werbungtreibende im Markenverband“ (OWM) are convinced that more and more consumers expect companies to show attitude and take responsibility (W\&V Editorial, 2019).

When companies voluntarily submit to ethical goals, they are quickly suspected of modern indulgence trading. It can appear that particularly moral behaviour in one place is intended to cover up misconduct elsewhere. If business ethics is not to be misused as an advertising tool, 
it is important to anchor the corresponding thinking and actions in everyday life (Frohne, 2020 , p. 30). For financial service providers, this means a special challenge, as the products are mostly complex and abstract (Schloz, 2020, p. 4). This requires sales units to act consistently and to build the customer's trust towards the brand and the personal advisor. (Hoppe, 2000, p. 3) At the same time, sales rests on many people, as the customers' high need for explanations is met with high staffing levels compared to other industries (Hellenkamp, 2018, p. 10; Möller, 2008, p. 204).

Against this background, it becomes clear that business ethics considerations should not be limited to corporate communication. According to Thummes (2019), the relationship between communicated values and their detectability in the actions of the acting persons is decisive for credibility (Thummes, 2019, p. 7). This makes it clear that client advisors in financial sales must have business ethics competence. The aim of this research is to clarify whether the necessary awareness has already arrived in the market. In addition, it is important to examine whether existing university training programmes for sales professionals in financial sales take sufficient account of this new facet of management.

\section{THEORETICAL BACKGROUND}

This paper examines the importance of business ethics for financial services sales in Germany. The focus is particularly on the necessity of taking ethical aspects into account relates a career as a sales manager. This is a multi-faceted topic, which is why it is first necessary to delineate the decisive terms.

\section{a. Definition financial service provider}

In accordance with the German Banking Act (KWG), Manzeschke \& Brink (2020) define credit institutions, insurance companies, building societies and credit brokers as financial service providers (Manzeschke \& Brink, 2020, p. 1409). The providers can be further classified according to the type of business model and the characteristics of the product range. Izzo-Wagner \& Siering (2020), for example, define a full-service bank as a company that is basically allowed to handle all banking transactions, financial services, payment services and e-money transactions (Izzo-Wagner \& Siering, 2020, p. 29). According to Hartung (2020), private providers of insurance products are considered insurance companies in distinction to this. In addition to covering traditional risks, an insurer's portfolio can also include investment products, for example, in the form of life and pension insurance. Although they have the same name, social insurance institutions do not belong to the group of insurance companies (Hartung, 2020). Furthermore, providers of other financial products such as closed-end and open-end investment funds also count as financial service providers. So do issuers of innovative financial services, the so-called fintechs (Thakor, 2020). 
All financial service providers assigned to the term so far can be summarized in the category providers. Another special feature of the German market is the existence of financial product distributors. These are economically and legally independent companies that broker financial products to end customers without offering their products. These sales organizations can be differentiated in terms of their legal and factual relationship with the respective providers into company-owned, company-linked and non-company sales channels (Hartmann, 2014, p. 20). In line with Farny (2011), Hartmann (2020) classifies all customer advisors permanently employed by a provider as company-owned sales. Single-company agents or group agents are considered company-affiliated. These customer advisors, also known as agencies, are economically independent and not directly bound by instructions. However, they exclusively broker products of a company or group and are contractually bound to it. The socalled brokers are to be regarded as external to the company. They broker products from different providers (Farny, 2011, 742 f). Both company-bound and non-company sales structures are referred to as indirect sales (Binckebanck, 2020, p. 24; Geest, 2020, p. 7).

In addition to the distinctive features already outlined, providers of financial services can also be differentiated according to their ownership structure. In this paper, the term 'returndriven providers' covers all those legal forms whose owners are interested in generating returns. These include, in particular, joint-stock companies, but also owner-managed companies such as brokerage offices. The counterpart to this are "customer-driven providers". This term is used by the authors of this paper to refer to those providers whose ownership lies with the customers. These are typically cooperatives or registered associations. In a broader sense, financial service providers owned by the public sector can also be assigned to this group, as they pursue welfare objectives in addition to their profit-making intentions. An example of this are the savings banks.

For this research, members of all distribution channels are considered. On the one hand, this is done in the knowledge that customer advisors are repeatedly active in different structures during their professional lives (Schmidt, 2019). On the other hand, it is based on the knowledge that providers of financial services like to recruit their own sales managers from indirect sales (ADAC Hessen-Thüringen e.V., 2021; Provinzial Rheinland, 2021; SIGNAL IDUNA).

\section{b. Definition of university education}

Anyone wishing to provide or advise on financial services in Germany requires a written permit before commencing business (BaFin Bundesanstalt für Finanzdienstleistungsaufsicht, 2021; IHK München und Oberbayern, 2021). The decisive factor for the granting of a licence is proof of the required expertise. To be allowed to advise on financial products and insurance products, a corresponding professional training or the passing of an expert knowledge 
examination at the IHK is necessary (Heegardt \& Kreye, 2020). Building on this, there are further job-related qualification measures, such as the Fachwirt für Versicherungen und Finanzen (Roth, 2021) or the Bankfachwirt (Frankfurt School of Finance \& Management, 2021). However, these educational programmes, which are also referred to colloquially as studies, are vocational educational programmes. They are designed to enable graduates to be professionally successful in their field.

For the purposes of this research, however, training programmes that serve to qualify people to take on management functions are to be examined. The background here is the approach that sales managers have a decisive influence on which corporate values are lived in customer advisory services. If the focus of financial service providers is increasingly on business ethics issues, this can be understood as a change process. It is then necessary to introduce new target values and let these become the self-image of the entire organization (Spiegel, 2020, p. 17). For this, as in other aspects of sales management, far-reaching personal management competences are required. Therefore, Belz et al. (2020) and Baier (2021) agree on the professionalization of the discipline of sales management (Belz, Lee, Huckemann, \& Weibel, 2020, p. 340). This has ensured that sales managers have increasingly used university education programmes in recent years (Baier, 2021). Against this background, study programmes are considered to be university-based, if they have an ECTS accreditation.

\section{c. Definition of business ethics}

The debate on ethical issues related to financial services is not a new phenomenon, but was introduced by Hößlinger (1930) (Hößlinger, 1930) and Kisch (1935) (Kisch, 1935). Since then, business ethics issues have been the subject of repeated research (Michael \& Abraham, 2009, p. 204; Raatzsch, 2014, p. 90; Riege, 1990). For a long time, the core topics were the fight against corruption, the prevention of white-collar crime and ensuring sufficient consumer protection (Hartmann, 2014, p. 1). It was not until the end of the 2010s that Maisch $\&$ Schick (2014), for example, began to make the ethical, social or ecological dimension of a financial product the subject of customer advice (Maisch \& Schick, 2014). According to Reisenauer (2010) and Wagner (2017) (Wagner, 2017, $25 \mathrm{f}$ ), this can be understood as a consequence of the financial crisis of 2007/2008 (Reisenauer, 2010, p. 149). A view that is also shared in the communication departments of the large German financial service providers. This is evidenced by campaigns that focus on ethical thinking instead of economic performance. The pioneer here was Commerzbank AG with its Econ Award-winning campaign "We have understood" (Commerzbank AG, 2013). Deutsche Bank also deleted its established clain "Performance with passion". Instead, it tries to underline its social commitment with the hashtag \#PositiveImpact (Mattgey, 2018). The communicative 
rethinking had become necessary, because the institutions had repeatedly and noticeably violated generally accepted principles of ethical behaviour.

In this context, it should be noted that the term ethics in the economic context is often used synonymously with the term business ethics. As Raith (2020) agrees with Noll (2013), this is not always correct. Rather, a distinction must be made between internal business ethics and external marketing ethics (Noll, 2013, p. 44; Raith, 2020, p. 5). This distinction can be understood as an attempt to resolve another dilemma. According to Poerschke (2021), this is because economic action is geared solely towards maximizing profit. Moral action, on the other hand, requires the inclusion of other target variables, which usually go together with a reduction in profit (Poerschke, 2021, p. 326). For this reason, Küpper (2006) defines economic expediency as well as social and ethical compatibility as independent principles of corporate governance in addition to legal permissibility (Küpper, 2006, p. 162).

According to Schneider (2020), marketing ethics deals with marketing-relevant behaviours and practices that are not regulated by laws, other legal norms or customary laws (Schneider, 2020). It is about the question of which value conflicts employees in marketing and sales are confronted with. The focus is on aspects such as honesty, fairness as well as price and product quality. The central question is how the interests of the company and the consumers can be reconciled (Kay-Enders, 2013, p. 18; Smith \& Murphy, 2012).

According to Petersen (2017), on the other hand, the object of business ethics is the social responsibility of a company (Petersen, 2017, $25 \mathrm{f}$ ). This is often attributed to companies and their management by the public (Wieland, 2004, p. 24). Sometimes companies and entrepreneurs also ascribe this moral obligation to themselves (Petersen, 2017, p. 25). This results from the economic self-image of actors within the theorem of the social market economy. However, Nolte (2021) notes that the economic system established in West Germany after the Second World War has long since developed into a discursive order (Nolte, 2021 , p. 3). Therefore, there is no agreement on the existence of an obligation to voluntarily assume social responsibility (König \& Schmidt, 2002). Gehlen \& Rehberg (2016) criticize in particular the lack of a concrete definition of responsibility relates business ethics. Furthermore, there are no consequences for the actors, if they do not fulfil their responsibility. This can lead to a devaluation of the concept of responsibility (Gehlen \& Rehberg, 2016, p. 152).

Aspects of both marketing ethics and business ethics are relevant to this research. On the one hand, the aim is to clarify whether business ethics approaches actually have greater weight today in setting corporate policy goals for financial service providers - and whether this has been sufficiently reflected in the training of sales professionals. On the other hand, it is also important to clarify whether these elements are reflected in the daily work of managers 
in financial sales. In this context, the question whether the integration of ethical goals is considered a success factor for business development and career planning will also be clarified.

\section{DATA AND METHODS}

In general, there is agreement that financial service providers are focused on making a profit (Dressler, 2020, p. 14). The strength of the desire for a high return diverges among providers of different legal forms. However, according to Karten et al. (2018), the desire to make a profit also exists, at least in the form of an indirect profit-making intention, in customerdriven legal forms such as the mutual insurance association (VVaG) (Karten, Nell, Richter, \& Schiller, 2018, p. 15). Against this background, sales in most companies today are still completely money-driven (Hartmann, 2014, p. 22; von Münch, 2020, p. 118). In this context, Beenken (2018) sees it as the task of sales management to ensure motivation in the sales team through appropriate incentives. This is necessary so that the company's goals can be achieved (Beenken, 2018, p. 95). Due to their high incentive effect and the associated high control character, material incentives in particular are used in the sales of financial services (Görgen, 2007, p. 208; Miebach, 2017, p. 346). According to Sennewald (2017), this increasingly leads to advisory appointments turning into pure sales talks (Sennewald, 2017, p. 114). In contrast, Schmitz (2017) recognizes dangers in the duality of financial sales staff. On the one hand, the balancing act between advice geared to the interests of the customer and economic dependencies means a strain. This can demotivate sales staff eventually or even have negative effects on their health. The consequences are uneconomical sick leave or the loss of competent staff (Schmitz, 2017, p. 325). However, monetary management also entails risks for the provider. Central to this is the danger that customers will be badly advised, notice this sooner or later and then leave. As Becker (2017) notes, this also entails the risk of financial losses. This is because if a premature cancellation of contracts, only part of the commission paid out can be reclaimed (Becker, 2017, p. 169).

Against this background, it becomes clear that providers of financial services have an economic interest in building and maintaining sustainable customer relationships (Cavigelli, 2019, p. 365; Mast, Huck-Sandhu, \& Güller, 2005, 49 ff). This is aligned with the public's growing need for more ethically correct behaviour for financial service providers and the associated, continuously growing regulatory framework (Hufeld, 2019; Köhne \& Melashenko, 2019, p. 277). Against this background, the author of this paper assumes that the ethical principles formulated by financial service providers are serious (Allianz SE, 2020; MLP SE, 2020; SIGNAL IDUNA, 2019). Therefore, ethical aspects should by now have arrived in the education system as well as in the sales units of financial service providers. 


\section{a. Analysis of university education programmes}

Financial service providers are increasingly committing themselves to ethical responsibility. They want to meet the associated requirements with various measures. These include, for example, investments in environmental protection, employee development and compliance with social standards - both in their own company and with cooperation partners (Erpenbeck \& Sauter, 2020, p. 235). This also includes the promotion of art, culture, and sport (Gibson-Kunze, 2021, p. 6) and the promotion of voluntary work (Hollmann, Kunzlmann, \& Riess, 2020, p. 211). The portfolio of business ethics aspects in financial sales is rounded off by the question of needs-oriented advice (Boden, 2016, p. 243).

As with all questions of corporate policy, there are diverging prioritizations in the named areas in different companies. However, an increasing interest in the moral balance of suppliers and their products can be observed on the customer side (Drost, 2020). On the one hand, this allows ethical thinking and action to mature into competitive advantages. On the other hand, interested and well-informed consumers can unmask statements, that are not meant seriously as clumsy marketing.

Against this background, sales professionals must have ethical competence in the future. This enables them to act consistently and build the necessary credibility. Furthermore, they will then be able to identify ethically correct offers for their customers and thus ensure longterm customer loyalty. There is a broad consensus on the importance of lifelong learning for sales professionals (Gouthro, 2017; Park \& Kim, 2020). This makes it all the more important to equip sales managers with a broad basic competence. This is why, as already explained, professionalization has set in over the last few years. This means that financial sales is following a general trend that has led to an enormous growth in study programmes. For example, according to the German Rectors' Conference (HRK), the number of degree programmes has increased from 11,265 in the winter semester $2007 / 2008$ to 20,359 in the winter semester 2020/21 (HRK German Rectors' Conference, 2020, p. 9).

For this paper, an analysis of the degree programmes offered to sales professionals will be conducted. According to Buckley (2018), a mixed methodology is used. Data obtained in a qualitative survey is coded and then analysed quantitatively (Buckley, 2018).

Following Palm (2012) and Tenscher (2003), it can be assumed that the importance of a topic goes together with its explicit mention or the number of mentions (Palm, 2012, p. 46; Tenscher, 2003, p. 291). Against this background, the database of the Zeit-Verlag, comprising a total of 420 German universities, is used to identify study programmes in the field of sales management. For this purpose, Bachelor's, Master's and MBA programmes as well as certificate programmes with the keyword "Sales Management" are queried (ZEIT Campus, 
2021). In addition, the Google search is also used to look for German-language degree programmes with this title abroad. A total of 51 degree programmes can be identified in this way. A relatively small number compared to the current total of 2,948 economics degree programmes approved in Germany (HRK German Rectors' Conference, 2020, p. 13).

In a further step, a qualitative content analysis of the study manuals is carried out. This step is necessary because purely quantitative methods are not suitable for determining causes and backgrounds (Lenger \& Kruse, 2017, p. 112). In addition, according to Mey \& Mruck (2014), a qualitative analysis is indicated if the quantitative evaluation only allows weak or less relevant hypotheses to be derived (Mey \& Mruck, 2014, p. 197). This situation is given in the present research project. On the one hand, the small number of degree programmes in sales management is a weak indication of the discipline's low relevance in the canon of business studies. On the other hand, this assumption contrasts with the public perception already outlined. It is therefore necessary to find out the background. This is done by analysing the curricula belonging to the identified study programmes.

Within the framework of the qualitative content analysis, it is determined which of the competences that are currently particularly in focus are explicitly dealt with in at least one module of the degree programmes. Within the scope of the analysis, the keywords business ethics, pricing, supply chain management, digitalization, leadership, change management, human resources management, sales strategy, innovation management and controlling are searched for. These search terms were chosen, because they represent currently relevant key competencies in financial sales (Binckebanck \& Götzen, 2017, p. 943; Dezhgahi, 2021, p. 105; Dukart, 2017; Karlshaus \& Segger, 2017, p. 98; Krämer \& Schmutz, 2020, p. 50; Lokuge \& Subasinghage, 2020; Martin, Elg, Gremyr, \& Wallo, 2021; Moodley \& Govender, 2020; Pekruhl, Vogel, \& Strohm, 2018; Rybakova, Vinogradova, \& Sizikova, 2019; Slone, Dittmann, \& Mentzer, 2014). During the evaluation, the study programmes are coded for the presence of the respective characteristics. In this way, it can be determined whether the study programmes acknowledge the topic of business ethics. On the other hand, it can be seen to what extent other trend topics in management are served. In this way, a comparison of the importance of different management competencies in the education of sales professionals becomes clear. The following hypothesis will be tested:

$H_{A}$ : Business ethics is a significantly important component of university courses in sales management.

Figure 2 lists all the study programmes examined. The programmes offered by iba University and SDI International University of Applied Sciences cannot be evaluated, as neither provider disclosed a curriculum. Thus, 48 study programmes are included in the analysis, the contents of which are coded. The coding is carried out as follows: If a module on 
the corresponding topic is available, the value 1 is assigned, otherwise 0 . Figure 1 shows in what percentage of the study programmes examined a certain topic is included.

\section{Figure 5}

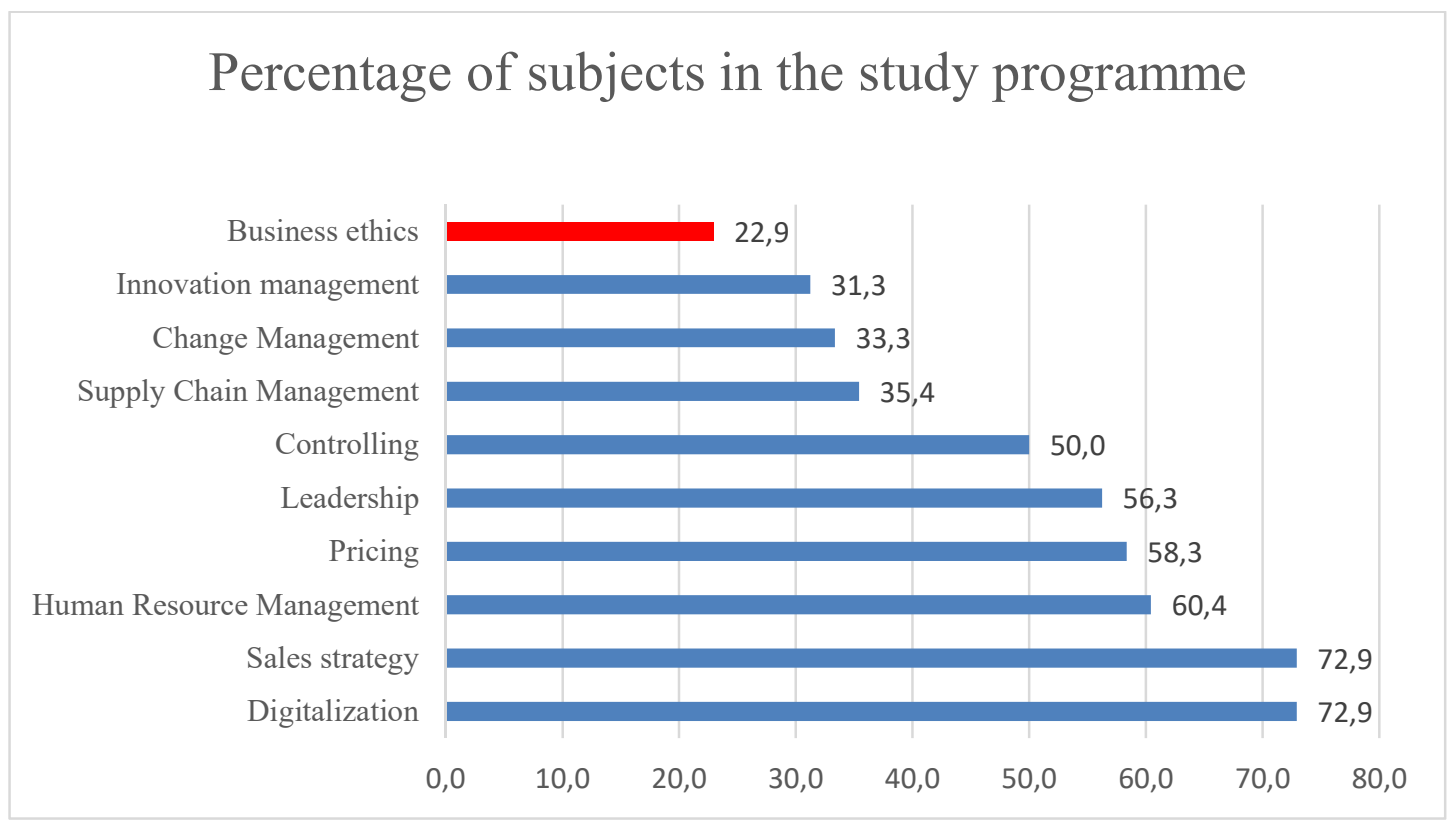

The research subject is the business sub-discipline of sales management (Dugan et al., 2020). Against this background, it is understandable that Sales Strategy and Digitalization are at the top with $72.92 \%$ each. After all, the sale of products and services is the central topic of sales management and digitalization is a mega-topic of our time (Glaser, 2017, p. 331; Wewer, 2020, p. 374).

What was not to be expected, however, was the appreciation of business ethics in the existing study programmes. Although, according to Priddat (2010), ethical consumption is becoming a significant economic factor and a further dynamization of the market can be expected (Priddat, 2010, p. 44), less than a quarter $(22.9 \%)$ of the study programmes examined include a corresponding module. As Priddat (2015) and Jäggi (2018) agree, this is not a temporary trend but a social change (Jäggi, 2016; Priddat, 2015).

To clarify the hypothesis HA, it is necessary to clarify, whether the topic of business ethics is taught significantly less frequently than the most frequently taught topics. Digitalization and sales strategy are used here as a reference value. The selection was made, because both topics are taught in around $73 \%$ of the study programmes examined and thus top the list of topics. 
Enz, C. Škodová Parmová, D., Wolf, P.

\section{Figure 6}

\begin{tabular}{|c|c|c|c|c|c|c|c|c|c|c|c|}
\hline Provider & Course of Studies & $\begin{array}{c}\text { Business } \\
\text { ethics }\end{array}$ & Pricing & $\begin{array}{c}\text { Supply } \\
\text { Chain } \\
\text { Manage- } \\
\text { ment }\end{array}$ & $\begin{array}{l}\text { Digitali- } \\
\text { zation }\end{array}$ & Leadership & $\begin{array}{l}\text { Change } \\
\text { Manage- } \\
\text { ment }\end{array}$ & $\begin{array}{c}\text { Human } \\
\text { Resource } \\
\text { Manage- } \\
\text { ment }\end{array}$ & $\begin{array}{l}\text { Sales } \\
\text { strategy }\end{array}$ & $\begin{array}{c}\text { Innovation } \\
\text { manage- } \\
\text { ment }\end{array}$ & $\begin{array}{l}\text { Con- } \\
\text { trolling }\end{array}$ \\
\hline Euro-FH & Sales und Management (B.A.) & 0 & 1 & 1 & 1 & 1 & 0 & 1 & 1 & 0 & 1 \\
\hline AKAD University & $\begin{array}{l}\text { Marketing- und Vertriebsmanagement } \\
\text { (Bachelor) }\end{array}$ & 0 & 1 & 0 & 1 & 0 & 0 & 1 & 1 & 0 & 1 \\
\hline iba University & Sales Management & - & - & - & - & - & - & - & - & - & \\
\hline FOM & Sales Management (M.Sc.) & 1 & 1 & 0 & 1 & 1 & 0 & 1 & 1 & 0 & 1 \\
\hline $\begin{array}{l}\text { ISM International School of } \\
\text { Management }\end{array}$ & $\begin{array}{l}\text { Business Administration Sales \& Brand } \\
\text { Management (B.A.) }\end{array}$ & 0 & 1 & 1 & 1 & 1 & 1 & 1 & 1 & 0 & 1 \\
\hline Ruhr Universität Bochum & Sales Management (M.Sc.) & 0 & 0 & 0 & 0 & 0 & 0 & 0 & 1 & 0 & 0 \\
\hline SRH Hochschule Heidelberg & Marketing Management \& Sales (BA) & 0 & 1 & 1 & 0 & 0 & 0 & 1 & 1 & 0 & 1 \\
\hline Europäische Fachhochschule & Sales Management (Bachelor) & 0 & 0 & 1 & 1 & 1 & 0 & 0 & 1 & 0 & 1 \\
\hline CBS International Business School & \begin{tabular}{|l|} 
Sales Management und \\
Vertriebspsychologie (M.A.) \\
\end{tabular} & 1 & 0 & 0 & 1 & 1 & 0 & 1 & 1 & 1 & 0 \\
\hline Universität Bayreuth & Marketing und Sales Management (MBA) & 0 & 0 & 0 & 1 & 1 & 0 & 1 & 1 & 0 & 0 \\
\hline SDI Internationale Hochschule & International Sales Management (M.A.) & - & - & - & - & - & - & - & - & - & - \\
\hline \begin{tabular}{|l} 
Hochschule für Wirtschaft und \\
Umwelt Nürtingen-Geislingen \\
\end{tabular} & $\begin{array}{l}\text { Digital Management, Marketing \& Sales } \\
\text { (MBA) }\end{array}$ & 0 & 0 & 0 & 1 & 1 & 1 & 1 & 1 & 0 & 1 \\
\hline $\begin{array}{l}\text { DHBW Duale Hochschule Baden- } \\
\text { Württemberg }\end{array}$ & Master Sales & 1 & 0 & 0 & 1 & 1 & 0 & 1 & 1 & 1 & 0 \\
\hline Victoria Internationale Hochschule & Sales Management (B.A.) & 1 & 1 & 0 & 1 & 1 & 1 & 0 & 0 & 1 & 1 \\
\hline Hochschule RheinMain & Sales and Marketing Management (M.A.) & 0 & 0 & 0 & 1 & 0 & 0 & 0 & 1 & 1 & 1 \\
\hline Hochschule Kempten & \begin{tabular}{|l|}
$\begin{array}{l}\text { International Sales Management } \\
\text { (Zertifikatsstudiengang) }\end{array}$ \\
\end{tabular} & 0 & 0 & 1 & 1 & 1 & 1 & 1 & 1 & 1 & 0 \\
\hline Quadriga Hochschule & Leadership \& Sales Management (MBA) & 1 & 1 & 1 & 1 & 1 & 0 & 1 & 1 & 1 & 1 \\
\hline Hochschule Aalen & \begin{tabular}{|l|} 
International Sales Management and \\
Technology (B.A.)
\end{tabular} & 0 & 1 & 0 & 1 & 1 & 0 & 0 & 1 & 1 & 0 \\
\hline Hochschule Wismar & Master Sales \& Marketing & - & - & - & - & - & - & - & - & - & - \\
\hline Hochschule Reutlingen & Strategic Sales Management (M.A.) & 0 & 0 & 0 & 0 & 0 & 1 & 0 & 0 & 0 & 0 \\
\hline Hochschule Kaiserslautern & Financial Sales Management (M.Sc.) & 0 & 1 & 0 & 1 & 1 & 0 & 1 & 1 & 1 & 1 \\
\hline $\begin{array}{l}\text { Ostfalia Hochschule für angewandte } \\
\text { Wissenschaften }\end{array}$ & Vertriebsmanagement (MBA) & 0 & 1 & 1 & 1 & 1 & 0 & 1 & 0 & 0 & 1 \\
\hline Fachhochschule Wiener Neustadt & $\begin{array}{l}\text { Business Development \& Sales } \\
\text { Management (MA) }\end{array}$ & 0 & 1 & 0 & 0 & 1 & 1 & 1 & 1 & 0 & 1 \\
\hline $\begin{array}{l}\text { German Graduate School of } \\
\text { Management \& Law }\end{array}$ & Master Vertriebsmanagement & 1 & 0 & 1 & 1 & 0 & 1 & 1 & 0 & 1 & 1 \\
\hline Fachhochschule der Wirtschaft & $\begin{array}{l}\text { Automotive Industry and Sales Management } \\
\text { (B.A.) }\end{array}$ & 0 & 1 & 1 & 1 & 1 & 1 & 1 & 0 & 0 & 1 \\
\hline $\begin{array}{l}\text { Hochschule der Wirtschaft für } \\
\text { Management }\end{array}$ & Beratung und Vertriebsmanagement (B.A.) & 0 & 1 & 0 & 1 & 1 & 0 & 1 & 1 & 0 & 0 \\
\hline Hochschule Konstanz & $\begin{array}{l}\text { Mechanical Engineering and International } \\
\text { Sales Management (M.Eng.) }\end{array}$ & 0 & 1 & 0 & 0 & 0 & 1 & 1 & 1 & 1 & 0 \\
\hline Fachhochschule der Wirtschaft & $\begin{array}{l}\text { Marketing- und Vertriebsmanagement } \\
\text { (M.A.) }\end{array}$ & 0 & 1 & 0 & 0 & 1 & 1 & 1 & 1 & 0 & 0 \\
\hline FH Bielefeld & Marketing und Sales (M.A.) & 0 & 0 & 1 & 0 & 1 & 1 & 1 & 0 & 0 & 0 \\
\hline iST Hochschule für Management & Hotelmarketing (Zertifikatsstudiengang) & 0 & 0 & 0 & 0 & 0 & 0 & 0 & 1 & 0 & 0 \\
\hline $\begin{array}{l}\text { HWZ Hochschule für Wirtschaft } \\
\text { Zürich }\end{array}$ & Sales Excellence (Zertifikatsstudiengang) & 0 & 0 & 0 & 1 & 0 & 0 & 0 & 0 & 1 & 0 \\
\hline FH Vorarlberg & International Marketing \& Sales (Master) & 1 & 1 & 0 & 1 & 1 & 0 & 0 & 1 & 0 & 1 \\
\hline Kalaidos Fachhochschule Schweiz & \begin{tabular}{|l|} 
Management und Sales \\
(Zertifikatsstudiengang)
\end{tabular} & 0 & 0 & 0 & 0 & 0 & 0 & 0 & 1 & 0 & 0 \\
\hline FH Wien & Marketing \& Sales (Bachelor) & 0 & 1 & 1 & 1 & 0 & 0 & 0 & 1 & 0 & 1 \\
\hline FH Wien & Marketing- \& Salesmanagement (Master) & 1 & 1 & 0 & 1 & 0 & 1 & 0 & 0 & 1 & 1 \\
\hline shh Fernhochschule & Digital Sales \& Marketing (M.Sc.) & 1 & 0 & 0 & 1 & 1 & 1 & 0 & 0 & 1 & 0 \\
\hline Rheinische Fachhochschule Köln & Vertriebsmanagement (Master) & 0 & 0 & 1 & 0 & 0 & 0 & 1 & 1 & 0 & 1 \\
\hline FH Münster & International Marketing \& Sales (Master) & 1 & 0 & 1 & 0 & 1 & 0 & 0 & 0 & 0 & 0 \\
\hline Universität Salzburg & Marketing- und Salesmanagement (EMBA) & 0 & 1 & 0 & 0 & 1 & 1 & 1 & 1 & 1 & 1 \\
\hline Hochschule Niederrhein & Sales and Marketing (B.A.) & 0 & 1 & 1 & 1 & 0 & 0 & 0 & 0 & 0 & 0 \\
\hline Universität St. Gallen & $\begin{array}{l}\begin{array}{l}\text { HSG-Intensivstudium Verkaufsmanagement } \\
\text { (Zertifikatsstudiengang) }\end{array} \\
\end{array}$ & 0 & 1 & 0 & 1 & 1 & 0 & 1 & 1 & 0 & 0 \\
\hline $\begin{array}{l}\text { Hochschule für Finanzwirtschaft \& } \\
\text { Management }\end{array}$ & Banking \& Sales (B.A.) & 0 & 1 & 0 & 1 & 0 & 0 & 1 & 0 & 0 & 0 \\
\hline Hochschule Furtwangen & $\begin{array}{l}\text { Wirtschaftsingenieurwesen - Sales \& } \\
\text { Service Engineering(MBA) }\end{array}$ & 0 & 1 & 1 & 1 & 1 & 0 & 1 & 1 & 0 & 1 \\
\hline Universität Passau & $\begin{array}{l}\text { B2B Marketing and Sales Management } \\
\text { (Master) }\end{array}$ & 0 & 1 & 0 & 1 & 0 & 0 & 0 & 1 & 0 & 0 \\
\hline LIMAK Austrian Business School & $\begin{array}{l}\text { Universitätslehrgang Sales Management } \\
\text { Excellence }\end{array}$ & 0 & 0 & 0 & 1 & 0 & 0 & 1 & 1 & 0 & 0 \\
\hline Fachhochschule der Wirtschaft Graz & Sales Management (Master) & 0 & 0 & 0 & 1 & 0 & 1 & 1 & 1 & 0 & 0 \\
\hline Fachhochschule der Wirtschaft Graz & Marketing \& Sales (Bachelor) & 0 & 1 & 0 & 1 & 0 & 0 & 0 & 0 & 0 & 1 \\
\hline ESCP Business School & $\begin{array}{l}\text { Master in International Sales Management } \\
\text { (MSc) }\end{array}$ & 1 & 1 & 1 & 1 & 1 & 1 & 0 & 1 & 0 & 1 \\
\hline $\begin{array}{l}\text { Friedrich-Alexander-Universität } \\
\text { Erlangen-Nürnberg }\end{array}$ & Marketing and Sales Management & 0 & 1 & 0 & 1 & 0 & 0 & 0 & 1 & 1 & 0 \\
\hline \begin{tabular}{|l} 
Zfh Zentrum für Fernstudien im \\
Hochschulverband
\end{tabular} & Vertriebsingenieur (MBA) & 0 & 0 & 0 & 0 & 1 & 0 & 1 & 1 & 0 & 0 \\
\hline Donau Universität Krems & Marketing und Vertrieb & 0 & 1 & 1 & 1 & 0 & 0 & 1 & 1 & 0 & 1 \\
\hline Total & & 11 & 28 & 17 & 35 & 27 & 16 & 29 & 35 & 15 & 24 \\
\hline Percent & & 22,92 & 58,33 & 35,42 & 72,92 & 56,25 & 33,33 & 60,42 & 72,92 & 31,25 & 50,00 \\
\hline
\end{tabular}


When evaluating Figure 2, it should be noted that there is a dependency for the modules under consideration within a degree programme, as they each belong to the degree programme of one university. For this reason, the McNemar's chi-square test is used to test the hypothesis HA. When carrying out the test, it turns out that the table is too sparse on the opposite diagonal. Here the value of 26 is below the required number of 30 . For this reason, a correction according to Edwards was made. The calculation is carried out with the statistical software R in version 4.0.3 (Revelle, 2020; Warnes et al., 2020; Wickham, 2016; Wickham \& Bryan, 2019).

For the calculation, the study programmes without evaluation are removed from Figure 2. The McNemar's chi-square test with Edwards correction shows significance $\left(x^{2}(1)=\right.$ $20.35, p<0.001$ ) which is why the null hypothesis must be rejected favouring $\mathrm{H}_{1}$. Thus, the formulated hypothesis $\mathrm{H}_{\mathrm{A}}$ must also be rejected.

\section{b. Importance of business ethics in sales practice}

This paper shows that business ethics is significantly less represented in the education of sales managers than other topics that are considered important in the public debate. At the same time, this research suggests that the courses offered by universities are demand-driven. This raises the question of what role business ethics aspects actually play for a career in sales. To this end, the authors conducted a survey in March 2021. Beforehand, a total of 789 sales executives from German financial service providers had been identified in the professional online networks XING and LinkedIn. These were contacted by email and invited to take part in an online survey. At the end of the survey period, which ran from 19 to 29 March, a total of $368(n=368)$ respondents took part.

Agreeing Rathgeber (2019) and Sotz-Hollinger (2009), the authors of this paper argue that students - especially in a part-time degree programme - view their learning as an investment in their career (Rathgeber, Edeling, \& Pilz, 2019; Sotz-Hollinger, 2009, p. 14). It can therefore be assumed that before enrolling in a degree programme for sales management, students intensively consider whether it contains those elements that seem particularly relevant for a career in sales. This leads to the assumption that sales staff in the financial services sector do not attach any particular importance to the topic of business ethics. The following hypothesis should therefore be tested regarding the contradiction between public perception and the existing range of studies:

$H_{B}$ : Business ethics competence is not of decisive importance for a career in sales. 
To clarify this, the large-scale survey asked how important sales professionals currently consider business ethics skills to be for a career in sales. A selection was made on a five-part scale between "absolutely unimportant" and "of decisive importance". To clarify the hypothesis, the distribution of the answers was analysed using R (packages: psych, ggplot2).

The distribution of the answers (Graph 2) is almost bimodal, whereby it should be noted that nobody saw the business ethics competences as meaningless for a career in sales. On average, the importance was rated at 3.48 (95\%-CI [3.37, 3.58], BCa bootstrap, $\mathrm{R}=1000)$. Overall, $43.5 \%$ of the participants see the competencies as important or even very important. This thus contradicts the importance that the universities seem to attach to business ethics according to the survey conducted.

It can also be observed that $56.5 \%$ of the respondents do not attribute any particularly high importance to the module business ethics regarding career prospects. On the other hand, 26\% of the respondents consider ethical competence to be particularly important - which is very close to the presence of the module in $22 \%$ of the study programmes. There is thus no reason to deviate from the null hypothesis. It follows that $\mathrm{HB}$ does not have to be rejected either. The sales employees do not assume that ethical competencies can have a significantly positive effect on career progression.

\section{Figure 7}

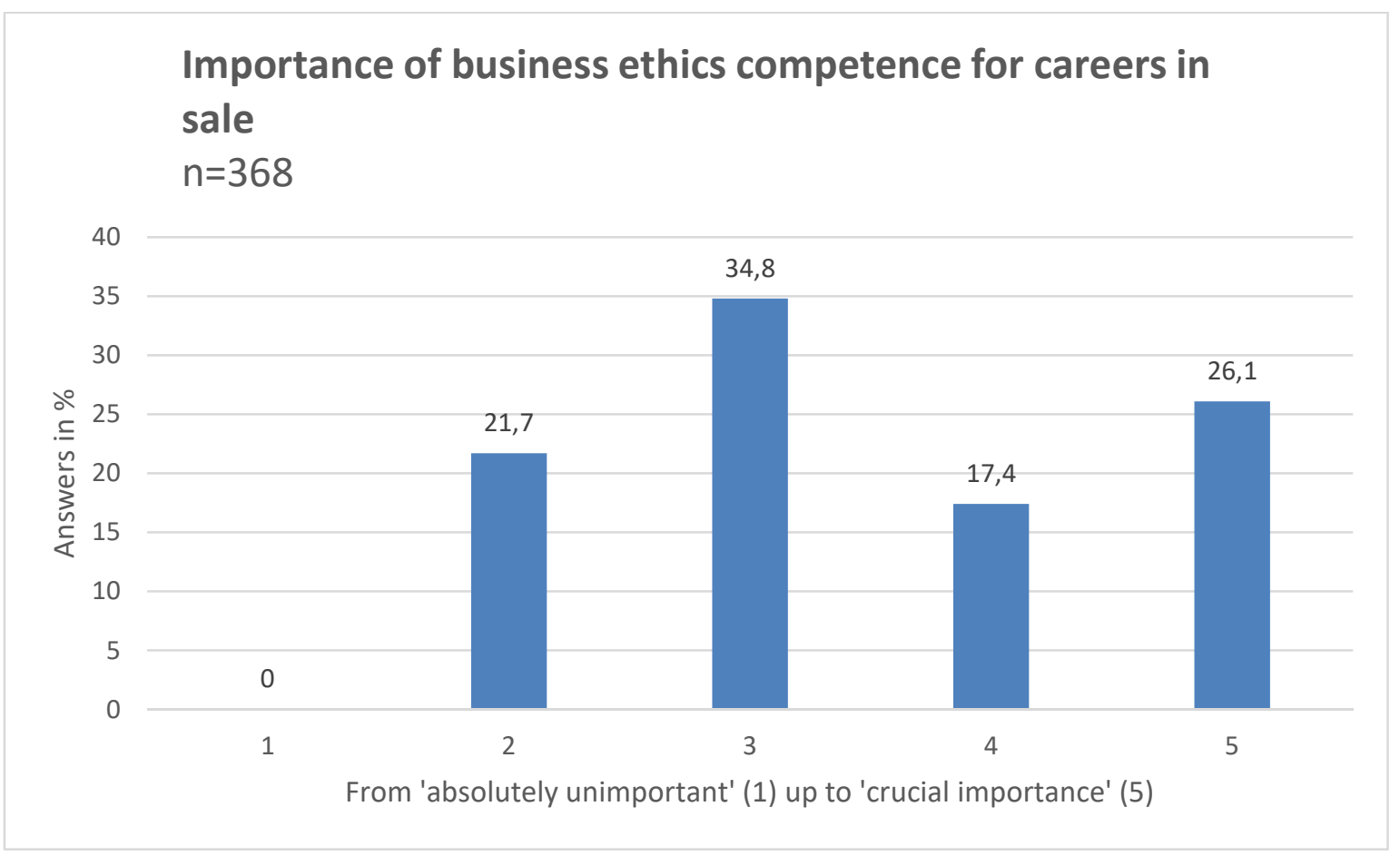

So, a contradiction is apparent here. On the one hand, the importance of business ethics is perceptible in society. On the other hand, business ethics aspects are considered to be of little 
importance for the course of a career in sales. Here, Richter \& Steen (2019), Rhein (2017) and Schmola (2015) provide an explanatory approach. They describe that ethical behaviour is often perceived as an activity outside of regular business operations. This is linked to the assumption that business ethics is a cost factor, that offers no economic benefit to the company (Rhein, 2017; Richter \& Steen, 2019, p. 76; Schmola, 2015). An assumption that is also tested in the survey. To this end, the subjects were asked how likely they thought it was, that a company that held business ethics correctly would be able to enforce better prices. This serves to test the hypothesis:

$H_{C}$ : Sales staff assume that higher prices can be achieved through ethically correct behaviour.

To answer the question, respondents could again choose from five levels. The scale ranged from "absolutely impossible" to "very likely". Graph 3 shows the distribution of the answers. On average, the possibility of being able to achieve higher prices through ethically correct behaviour was rated with 3.14 (95\%-CI [2.98, 3.29], BCa bootstrap, $\mathrm{R}=1000)$. Overall, 36.4\% of the participants see an advantage in the sales talk as very likely. However, the expression 4 "probably" does not occur even once. On the other hand, $64 \%$ of the respondents see no or only manageable possibilities of being able to obtain better prices for a product provider who is considered ethically correct.

\section{Figure 8}

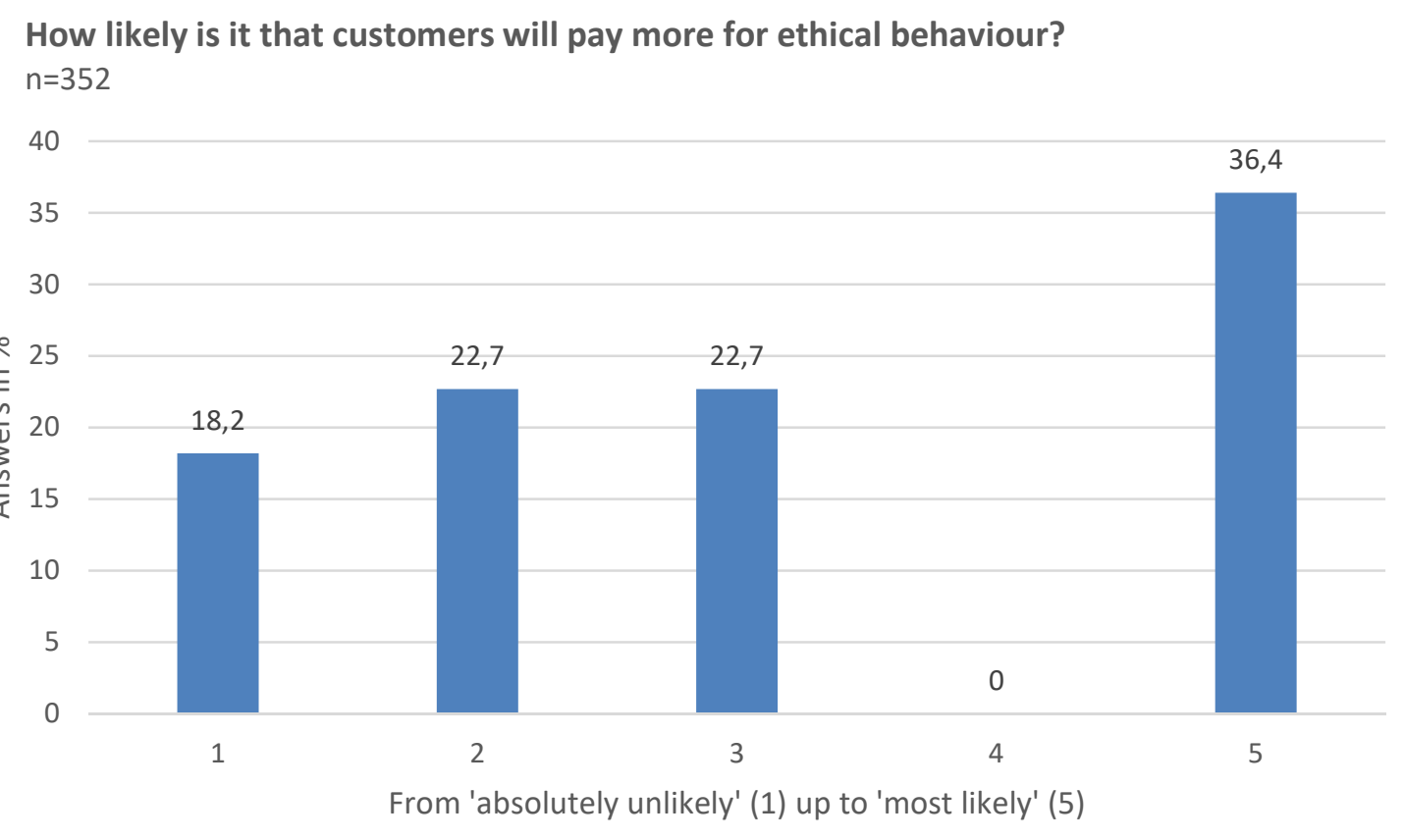


Considering this clear distribution, the authors believe that the null hypothesis should be accepted. This states that ethical behaviour has no influence on the prices to be achieved. Thus, the hypothesis formulated as HC must also be rejected. Thus, the distributors do not see any significant possibility of developing ethical aspects into a competitive advantage.

Overall, the image of financial service providers has been poor for some time. This is shown by a survey conducted by the GfK Gesellschaft für Konsumforschung in 2016. In the customer survey, only 35 percent of the respondents agreed with the statement "banks and insurance companies are trustworthy". This means that financial service providers achieved the worst value of all in a sector comparison (Leipzig Chamber of Skilled Crafts, 2017). However, it should not be forgotten that there is no one financial service provider. A distinction can be made here according to the type of services provided. Examples include banks, insurance companies, investment companies and brokers. It is also possible to differentiate according to legal form and thus ultimately also according to ownership structure.

Within these categories of financial service providers, differences in image can be observed. A study commissioned by the German Savings Banks and Giro Association (Deutscher Sparkassen- und Giroverband) from Kantar, for example, shows that $55 \%$ of the population have a very high level of trust in the savings banks. This is the highest value, ahead of the cooperative banks with $46 \%$. Only $24 \%$ attest a very high level of trustworthiness to Deutsche Bank, and the Fintech N26 receives the lowest score with 13\% (DSGV Deutscher Sparkassen- und Giroverband e.V., 2020, p. 26). In this study, financial service providers owned by customers perform far better than private providers that are fully focused on making a profit. This raises the possibility that the sales staff of the respective groups also have a different understanding of the topic of business ethics, which is a decisive factor in building trust according to Rommerskirchen \& Woll (2015) (Rommerskirchen \& Woll, 2015). In addition, it seems reasonable to assume that ethics are more important in customer-dominated companies than in return-oriented financial service providers. This assumption will be examined:

$H_{D}$ : Employees of return-oriented and client-oriented financial service providers rate the importance of business ethics competences differently.

As a test procedure for the hypothesis HD, a t-test with Welch correction is carried out. The effect size is calculated according to Cohen (Cohen, 2013). A test of normal distribution is waived about the central limit theorem and the group sizes (Figure 5). According to Rasch et 
al. (2011), the prerequisites for the Welch test are thus fulfilled (Rasch, Kubinger, \& Moder, 2011).

Graph 4 visualizes the confidence intervals of the two comparison groups "Customerspecific" and "Yield-determined". This is already a first indication that there can be significant differences in the evaluation of business ethics competences. This impression is confirmed by the calculation of the Welch t-test and the consideration according to Cohen.

\section{Figure 9}

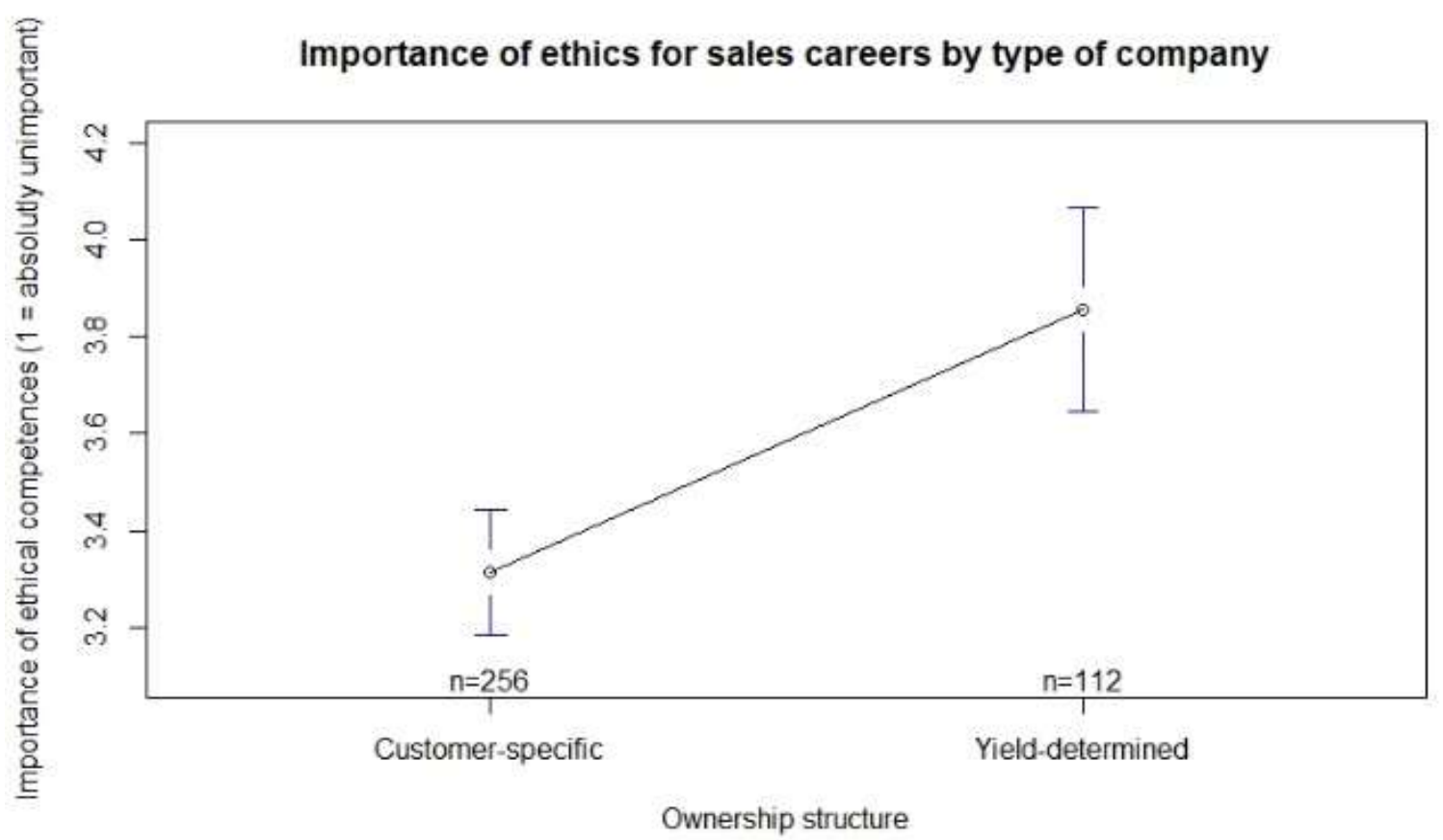

Thus, the Welch $\mathrm{t}$-test $(\mathrm{t}(197.74)=-4.35, \mathrm{p}<0.001)$ shows that employees of return-oriented companies rate the importance of ethical competencies for a career in financial sales significantly higher on average $(\mathrm{m}=3.86, \mathrm{sd}=1.13$, median $=4, \mathrm{n}=112)$ than employees of customer-driven companies $(\mathrm{m}=3.31, \mathrm{sd}=1.05$, median $=3, \mathrm{n}=256)$. The mean difference is $0.545(95 \%-\mathrm{CI}[0.29,0.79])$. The effect size according to Cohen (1992) is $\mathrm{r}=0.48$ and thus corresponds to a medium effect.

In addition to assessing the importance of business ethics competence in general, the respondents were also asked to rate its importance for a career in their own company. The analysis of these results follows the same path. 


\section{Figure 10}

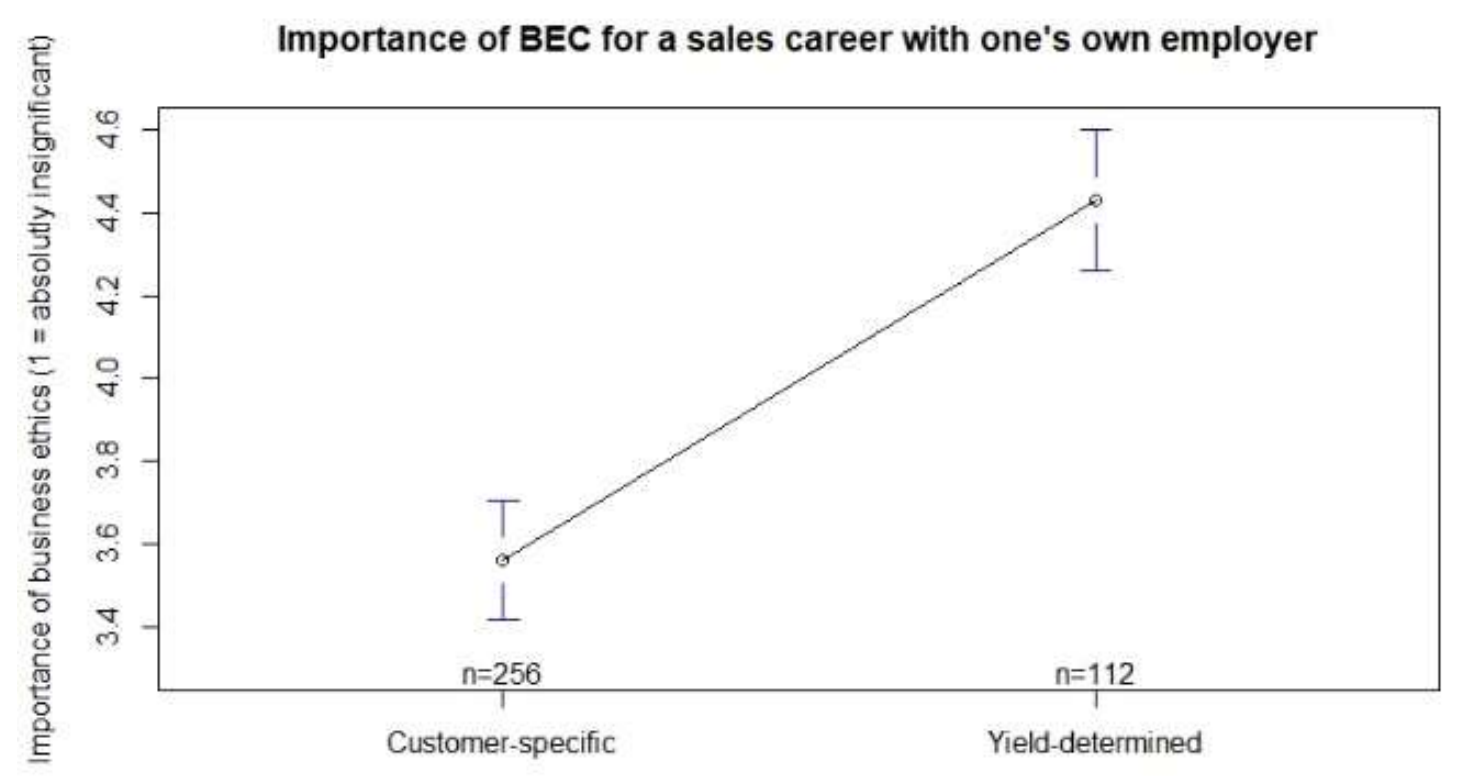

Ownership structure

Figure 6 visualizes the confidence intervals of the two comparison groups "Customerspecific" and "Yield-determined". This is already an indication that there can be significant differences in the evaluation of business ethics competences. Since the slope is even steeper in comparison to graph 5, an even stronger effect is to be expected than in the previous calculation.

Thus, the analysis (Welch test, $\mathrm{t}(269.85)=-7.68, \mathrm{p}<0.001$ ) shows that employees of returnoriented companies rate the importance of business ethics competencies for a career in the company in which they themselves are employed significantly higher on average $(m=4.43$, $\mathrm{sd}=0.91$, median $=5, \mathrm{n}=112)$ than employees of customer-oriented companies $(\mathrm{m}=3.56$, $\mathrm{sd}=1.17$, median $=4, \mathrm{n}=256$ ).

The mean difference is 0.545 (95\%-CI [0.29, 0.79]). The effect size according to Cohen (1992) is $r=0.95$ and thus corresponds to a strong effect.

Thus, the null hypothesis must be rejected favouring the alternative hypothesis. This hypothesis states that the significance of business ethics aspects depends on the ownership structure of a financial service provider. Accordingly, the hypothesis formulated as HD must be accepted. Employees of return-oriented and customer-oriented financial service providers rated the importance of business ethics competencies significantly differently. 


\section{RESULTS AND DISCUSSION}

As part of this research, a large-scale survey of sales professionals in the financial services sector was conducted. In a part of this survey, sales executives gave their opinion on the importance of business ethics for their employer. Like it is shown in Figure 7, the survey revealed that the importance of business ethics has increased particularly in companies, that had already identified this aspect as an area for action in 2016. Financial service providers that had no increased interest in business ethics aspects five years ago have not developed them either - their number remained almost constant.

This can also be attributed to the fact that the distribution of financial services is often carried out by SMEs. Their management often acquired their competence in decades of practical activity - without underpinning it theoretically. This is significant because in such SMEs, in particular, decisions are often not made rationally. In addition, business management competence is often insufficient (Enz, 2019b, p. 9). Against this background, it is possible that the strategic importance of business ethics can only be recognized later.

\section{Figure 11}

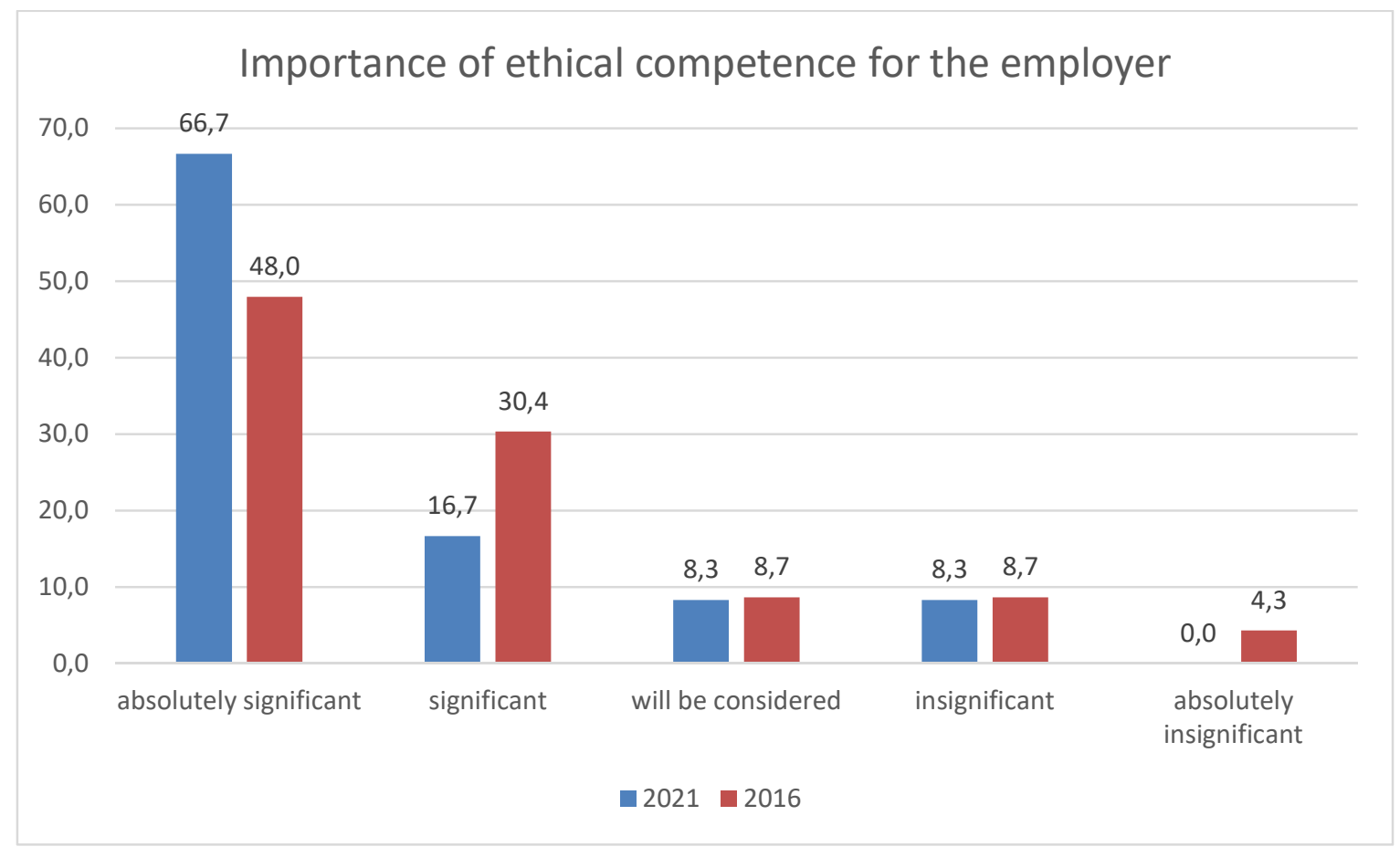

From this development, an increase in the importance of ethically correct behaviour for financial service providers can be derived. However, this is not yet reflected in the requirements for sales managers. They are aware of the growing interest of consumers in the ethical behaviour of providers in the financial services sector. However, only $36 \%$ of sales 
professionals believe they can currently achieve a higher margin with this. Against this background, business ethics competences are currently not among the central prerequisites whose existence qualifies for the next career level. Following Škodová Parmová (2021), this can also be explained by the realization that apparent mega-trends have repeatedly emerged in economics in the recent past. As different as these were thematically what they had in common was a short half-life. (Škodová Parmová, 2021, 7 f) Meanwhile, the increasing competitive pressure in the financial sector has also reached the regional providers who have long been decoupled from global market events (Enz, 2019a, p. 185). This is accompanied by strong cost pressure, which seems to be forcing numerous financial service providers to focus on their core competences (Reifner, 2017, p. 348). Contrary to what marketing would have us believe, the ethically based assumption of responsibility for employees, society, and the environment is obviously not one of them.

However, this focus on the direct monetary or career value of ethical action carries dangers. This is because purchasing decisions are traditionally the product of various influences. According to Enz \& Škodová Parmová (2020), it is therefore not enough to focus on individual factors. Rather, the interaction of different influences must be considered. Should business ethics creep to become a central issue in sales, there is a risk of an unnoticed loss of market opportunities and career options (Enz \& Škodová Parmová, 2020, p. 154). The extent of this risk is already shown by the fact that its importance is rated significantly higher in return-oriented companies than in customer-dominated financial service providers.

Sales management degree programmes present a similar picture. There are now various offers at Bachelor's level, Master's level and as an MBA. However, only just under a quarter of the educational measures explicitly include business ethics aspects.

\section{CONCLUSION}

As already explained, there is a trend towards ethics among German financial service providers. This shows itself in different ways. For example, ethical thinking can be an integral part of a financial service provider's business model, as is the case with GLS Bank in Bochum (GLS Gemeinschaftsbank eG, 2021). In addition, industry associations and interest groups are committed to ethical codes and quality standards (Börner). This can ensure transparency and quality of advice, and thus be in the interest of customers and ultimately society as a whole. However, the driving force for this action is not the consensus on the existence of an ethical obligation towards humans, animals, and nature. The background can also be the concern 
about further regulation and stronger control (AfW Der Bundesverband Finanzdienstleistung e.V., 2021).

In addition, there are now numerous financial products that are declared as particularly ethical or sustainable. They are provided by conventional service providers (DekaBank Deutsche Girozentrale, 2021; Union Investment Privatfonds GmbH, 2021), which can set other priorities in their main business (Mulke, 2021). As the magazines DasInvestment and Test lament, there is currently also no fixed definition of which financial products can be described as sustainable or ethically correct (Messner, 2020; Stiftung Warentest, 2021).

Beenken (2019) points out that the question whether trade can be conducted ethically has been unresolved for millennia. (Beenken, 2019, p. 15). However, this should not lead to a restoration in thinking any more than the current regulation, which is excessive in part (Versicherungsmagazin.de, 2019). This is because this paper shows, agreeing Pietsch (2019), that consumers will increasingly expect ethical behaviour from their financial service providers in the future. This results from the fact that people are increasingly aware that changes are necessary to preserve living space and quality of life in the long term (Pietsch, 2019). Currently, this realization does not seem to be shared by many financial service providers. However, corporate communication and product management have already recognized the trend and are responding to it with offers.

However, the survey conducted as part of this research clearly shows that thinking and acting ethically is not forbidden among financial service providers. However, from the sales perspective, it does not currently contribute significantly to the achievement of goals. In addition, sales professionals do not consider ethical aspects to be suitable for generating more business or for supporting their careers. This underpins the fear expressed by Jäggi (2018) that ethical-moral aspects are reduced to their function as a marketing tool (Jäggi, 2018, p. 28). For established providers, this poses the risk of losing their customers to consistent market participants in the medium term. These can be established competitors who have so far received little attention in the niche. But they can also be new market participants who see an opportunity to redivide the market. This is because new technical possibilities create more transparency on the demand side. In addition, the internet means that in many cases physical proximity is no longer necessary (Avramakis, 2020).

In this context, it is also noteworthy that the importance of ethically correct behaviour is already rated much higher in profit-oriented companies than in customer-dominated companies. This is surprising at first glance, since savings banks and cooperative banks in particular use their business philosophy, which is apparently oriented towards the common 
good, to distinguish themselves from the majority of purely commercial providers (BlomeDrees \& Zeuch, 2018; Läsch-Weber, 2020; Schütt \& Schulte, 2020). At a second glance, however, it becomes clear that there are financial service providers that have built up great trust in their history. Moreover, they are mostly SMEs. These are two reasons, why providers are not as much in the public eye as corporations such as Deutsche Bank or Allianz. This can lead to these institutions lulling themselves into a sense of security - and believing that they do not have to apply quite such strict standards to their business philosophy (Bender, 2021; Gütling, 2021). Or they think that ethically correct behaviour is part of their business policy anyway - which is why there is no need to talk about it. Both ways of thinking can contribute to a loss of trust and a deterioration of the market position, because ethical thinking and sustainable action will not be a unique selling point in the future, but the norm. Recognizing this change as an opportunity offers the possibility to position oneself for the future (Vlčková \& Jakubcová, 2019, p. 93).

The financial services sector, similar to tourism, is an industry that depends heavily on the performance of its employees. They maintain direct contact with customers and are the strongest, if not the only, way to differentiate themselves from competitors with the same service portfolio (Youn, Lee, \& Lee, 2018). However, Jarkovská (2020) and Yao et al. (2019) agree that the focus of business ethics issues is on the relationship between organizations and owners or external stakeholders. However, employee behaviour is still largely ignored (Jarkovská, 2020, 10 f; Yao, Qiu, \& Wei, 2019).

This contradicts the insight described by Vrchota \& Řehoř (2019) that companies cannot achieve their goals, if they do not succeed in taking their employees with them (Vrchota \& Řehoř, 2019). In this context, it is important to anchor ethical aspects in the behaviour of sales managers and sales professionals. However, the technical knowledge required for this is still too rarely included in the curricula of university programmes for sales professionals. In this context, however, it must be considered that successful sales employees and sales managers do not have a classical academic career. They often discover the need to underpin their competence theoretically in everyday practice. This is a trend that can also be observed in other industries. This is why the number of distance learning students in Germany has risen steadily in recent years (Klesper). Currently, about 160,000 distance learners are enrolled in Germany. The number has regularly increased by $7 \%$ in recent years.

Since there is only one state-run distance learning university in Germany, the majority of distance learners are enrolled at private universities. These are in competition with each other and regularly create new study programmes (Allensbach Hochschule, 2020). At iu 
International University alone, the largest private provider, there are currently more than 150 Bachelors, Masters and MBA programmes (iu Internationals Hochschule, 2021). However, universities can only act as providers of educational offers. It is the task of the economy to demand these and to establish the contents taught there traditionally (Marešová et al., 2020a, p. 6). The fact that there are only a few study programmes explicitly for sales managers indicates low demand in this context. The aspect that just $5 \%$ of these study programmes explicitly deal with the topic of business ethics suggests low interest among the student body in this subject area. The question whether this is due to a still low level of professionalization of the professional field of sales management could be the subject of further research. Following Marešová et al. (2020), the socio-economic driving force of universities should not be disregarded in this context. This can be used to further advance the professionalization of the field and the acceptance of business ethics competences (Marešová et al., 2020b, p. 24). This paper can therefore also be understood as an impetus for the development of new study programmes and measurement systems.

The results of this study can also be seen as an indication of a lack of innovative strength in the corporate organization of traditional financial service providers. This would be the case, if the low level of interest in business ethics competences was because existing structures prevented the consideration of ethical aspects (Marešová et al., 2020a, p. 11). Thus, this paper can also serve as a basis for the development of new ethical sales targets. There is still a need for this in companies that seriously want to create ethical foundations in sales management.

\section{REFERENCES}

ADAC Hessen-Thüringen e.V. (2021). Sie denken, ein Job sollte viele Facetten haben? Wir auch. Retrieved from https://www.jobware.de/job/detail/filialleitung-m-wd.535328315.html

AfW Der Bundesverband Finanzdienstleistung e.V. (2021). Agenda. Retrieved from https://www.bundesverband-finanzdienstleistung.de/agenda/

Allensbach Hochschule (2020). Fernstudieren in Deutschland: Zahlen und Fakten. Retrieved from https://www.allensbach-hochschule.de/fernstudieren-in-deutschland-zahlen-undfakten/

Allianz SE (2020). Verhaltenskodex der Allianz Gruppe: Das Richtige tun, um die Zukunft zu sichern. Retrieved from https://www.allianz.com/de/ueber-uns/strategiewerte/compliance/verhaltenskodizes.html

Avramakis, E. (2020). Wie "smarte Technologien" das Management der Kundenbeziehung verändern werden. In M. Stadelmann, M. Pufahl, \& D. D. Laux (Eds.), CRM goes digital: Digitale Kundenschnittstellen in Marketing, Vertrieb und Service exzellent gestalten und nutzen (pp. 219-240). Wiesbaden: Springer Fachmedien Wiesbaden. 
BaFin Bundesanstalt für Finanzdienstleistungsaufsicht (2021). Finanzdienstleistungen. Retrieved from https://www.bafin.de/dok/13733440

Baier, M. (2021, March 26). Interview by C. Enz. Berlin.

Becker, T. (2017). Mathematik der privaten Krankenversicherung. Studienbücher Wirtchaftsmathematik. Wiesbaden: Springer Fachmedien Wiesbaden.

Beenken, M. (2018). Vertriebsmanagement: Fach- und Führungskompetenz für die Assekuranz : geprüfter Fachwirt für Versicherungen und Finanzen, geprüfte Fachwirtin für Versicherungen und Finanzen (4., aktualisierte Auflage). Karlsruhe: VVW.

Beenken, M. (2019). Versicherungsvertrieb: Absatz von Versicherungen durch Versicherer und Vermittler in Theorie und Praxis (2. Auflage).

Belz, C., Lee, Y.-C., Huckemann, M., \& Weibel, M. (2020). Sales Excellence Development Sparten- und länderübergreifende Verkaufsentwicklung. In L. Binckebanck, A.-K. Hölter, \& A. Tiffert (Eds.), Edition Sales Excellence. Führung von Vertriebsorganisationen: Strategie - Koordination - Umsetzung (pp. 337-354). Wiesbaden: Springer Fachmedien Wiesbaden.

Bender, R. (2021, February 1). Staatsanwaltschaft ermittelt gegen weiteren SparkassenMitarbeiter in Nordhessen. Handelsblatt. Retrieved from https://www.handelsblatt.com/finanzen/banken-versicherungen/banken/skandal-beisparkasse-staatsanwaltschaft-ermittelt-gegen-weiteren-sparkassen-mitarbeiter-innordhessen/26864200.html?ticket=ST-293014-IEnYVuQWbfrLICAz4r0F-ap5

Binckebanck, L. (2020). Grundlagen zum strategischen Vertriebsmanagement. In L. Binckebanck, A.-K. Hölter, \& A. Tiffert (Eds.), Edition Sales Excellence. Führung von Vertriebsorganisationen: Strategie - Koordination - Umsetzung (pp. 3-34). Wiesbaden: Springer Fachmedien Wiesbaden.

Binckebanck, L., \& Götzen, R. (2017). Marketing für Wohnimmoblien. In D. Arnold, N. B. Rottke, \& R. Winter (Eds.), Wohnimmobilien: Lebenszyklus, Strategie, Transaktion (pp. 925-986). Wiesbaden: Springer Fachmedien Wiesbaden.

Blattner, P. (2003). 3. Zusammenfassung. In P. Blattner (Ed.), Globales Risikomanagement für Banken (pp. 371-380). Oldenbourg Wissenschaftsverlag. https://doi.org/10.1515/9783486815221-004

Blome-Drees, J., \& Zeuch, M. (2018). Genossenschaftliche Förderbilanz 2016 der Raiffeisenbank Main-Spessart eG. Zeitschrift für öffentliche und gemeinwirtschaftliche Unternehmen, 41(1-2), 81-91. https://doi.org/10.5771/0344-9777-2018-1-2-81

Boden, L. (2016). Bedarfsorientierte Beratung versus aktiver Bankvertrieb - Ein Widerspruch? In D. Hellenkamp \& K. Fürderer (Eds.), Handbuch Bankvertrieb: Theorie und Praxis im Zukunftsdialog (pp. 241-254). Wiesbaden: Springer Fachmedien Wiesbaden.

Börner, K. Prüfung - Regulatorik im Vertrieb - GDV Verhaltenskodex. Retrieved from https://www.bdo.de/de-de/branchen/versicherungen/pruefung-versicherungen/gdvverhaltenskodex

Buckley, R. (2018). Simultaneous Analysis of Qualitative and Quantitative Social Science Data in Conservation. Society \& Natural Resources, 31(7), 865-870. https://doi.org/10.1080/08941920.2018.1446232

Cavigelli, M. (2019). Kundenkommunikationsmanagement in der Versicherungswirtschaft. In M. Reich \& C. Zerres (Eds.), Rockwell Academy. Handbuch Versicherungsmarketing (2nd ed., pp. 363-388). Berlin, Heidelberg: Springer Berlin Heidelberg.

Chesney, M., Krakow, J., Maranghino-Singer, B., \& Münstermann, L. (2018). Asset Pricing: Finanzderivate und ihre Systemrisiken. Wiesbaden: Springer Fachmedien Wiesbaden. 
Cohen, J. (2013). Statistical Power Analysis for the Behavioral Sciences (2nd ed.). Hoboken: Taylor and Francis. from http://gbv.eblib.com/patron/FullRecord.aspx?p=1192162

Commerzbank AG (2013). Econ Award Unternehmenskommunikation zeichnet Werbekampagne der Commerzbank aus: Presseschau Banking vom 25. Oktober 2013. Retrieved from https://www.commerzbank.de/de/hauptnavigation/presse/medienmonitor/Medienmonito r_1.html

DekaBank Deutsche Girozentrale (2021). Lassen Sie grünen Ideen Flügel wachsen. Werden Sie Sinnvestor.: Nachhaltige Geldanlage. Retrieved from https://www.deka.de/privatkunden/anlageideen/nachhaltigkeit?campID=SEA-

Performance-Google-dekanachhaltigkeit\&gclid=Cj0KCQjw9YWDBhDyARIsADt6sGbX2bjTLKni_42L3NCp52 5i2ZWHjJIj_TqEbPLoUKL9s-2z8eTy9xgaAtoiEALw_wcB

Deutsche Bundesbank (2020). Anzahl der Kreditinstitute in Deutschland in den Jahren von 1957 bis 2019.

Dezhgahi, U. (2021). Die Auswahl von Schulleitern in einem Assessment Center. Wiesbaden: Springer Fachmedien Wiesbaden.

Dressler, S. (2020). Effektives Vermögensmanagement: Mehr Wert für alle (1. Auflage). Stuttgart: Verlag W. Kohlhammer.

Drost, F. (2020, August 26). Nachhaltige Geldanlagen liegen im Trend: Studie in Deutschland. Handelsblatt. Retrieved from https://www.handelsblatt.com/finanzen/anlagestrategie/trends/studie-in-deutschlandnachhaltige-geldanlagen-liegen-im-trend/26125020.html?ticket=ST-12211432ubSZgchnGkgvP1RGZLU-ap5

DSGV Deutscher Sparkassen- und Giroverband e.V. (2020). Die Deutschen und ihr Geld. Berlin: Deutscher Sparkassenverlag.

Dugan, R., Rangarajan, D., Davis, L., Bolander, W., Pullins, E. B., Deeter-Schmelz, D., . . . Agnihotri, R. (2020). Sales management, education, and scholarship across cultures: Early findings from a global study and an agenda for future research. Journal of Personal Selling \& Sales Management, 40(3), 198-212. https://doi.org/10.1080/08853134.2020.1781649

Dukart, R. (2017). Messen oder vergessen: Identifikation und Validierung von Leistungsmetriken von Produktionsnetzwerken. Rothenburger Wirtschaftsschriften: Band 1. Rothenburg: Christian Enz - Verlag für Wirtschaft und Wissenschaft Rothenburg.

Elodie, S., Absi, N., \& Borodin, V. (2020). Towards circular economy in production planning: Challenges and opportunities: Production, Manufactoring, Transportation and Logistics. European Journal of Operational Research. (287 (1)), 168-190.

Enkelmann, W.-D., \& Priddat, B. P. (Eds.) (2014). Was ist? Wirtschaftsphilosophische Erkundungen; Definitionen, Ansätze, Methoden, Erkenntnisse, Wirkungen. Reihe Wirtschaftsphilosophie: Band 3,1. Marburg: Metropolis-Verlag.

Enz, C. (2019a). Special requirements for corporate communications in geographically defined markets using the example of the sale of construction financing in rural areas. Balkans Journal of Emerging Trends in Social Sciences, 2(2), 185-193. https://doi.org/10.31410/Balkans.JETSS.2019.2.2.185-193

Enz, C. (2019b). Special requirements for corporate communications in geographically defined markets using the example of the sale of construction financing in rural areas. In B. Vuk (Ed.): International Scientific Conference ERAZ - Knowledge Based Sustainable Development, Book of Abstracts: Part of ERAZ Conference Collection (p. 9). 
Association of Economists and Managers of the Balkans, Belgrade, Serbia. Retrieved from https://eraz-conference.com/wp-content/uploads/2020/04/ERAZ_BoA-WEB.pdf

Enz, C., \& Škodová Parmová, D. (2020). Significance of digital communication channels for tourism providers in holiday regions. DETUROPE - The central european Journal of regional development and tourism, 12(2), 140-165.

Erpenbeck, J., \& Sauter, W. (2020). Die Wertegesellschaft: Formen - Folgerungen - Fragen. Berlin, Heidelberg: Springer Berlin Heidelberg.

Fabisch, N. (2017). CSR 4.0 und neue Arbeitswelten - (auch) eine Frage der Haltung. In B. Spieß \& N. Fabisch (Eds.), Management-Reihe Corporate Social Responsibilitiy. CSR und neue Arbeitswelten: Perspektivwechsel in Zeiten von Nachhaltigkeit, Digitalisierung und Industrie 4.0 (pp. 3-27). Berlin, Heidelberg: Springer Berlin Heidelberg.

Farny, D. (2011). Versicherungsbetriebslehre (5., überarb. Aufl.). Karlsruhe: VVW Verl. Versicherungswirtschaft.

Frankfurt School of Finance \& Management (2021). Bankfachwirt-Studium. Retrieved from https://www.frankfurtschool.de/home/programmes/weiterbildungsprogramme/bankfachwirt

Frohne, J. (2020). Brand Purpose in aller Munde. Was gilt es in der werthaltigen Kommunikation von Marken zu beachten? Transfer - Zeitschrift für Kommunikation und Markenmanagement, 66(2), 28-35.

Geest, D. (2020). Marketingkonzepte für jedermann: Crashkurs (1. Auflage). Norderstedt: BoD - Books on Demand.

Gehlen, A., \& Rehberg, K. S. (2016). Moral und Hypermoral: Eine pluralistische Ethik (7th ed.). Klostermann RoteReihe: v.5. Frankfurt am Main: Klostermann Vittorio. Retrieved from http://gbv.eblib.com/patron/FullRecord.aspx?p=4530937

Gibson-Kunze, M. (2021). Corporate Citizenship: (gesellschaftspolitische Rolle von Unternehmen). In L. Heidbrink, A. Lorch, \& V. Rauen (Eds.), Praktische Wirtschaftsphilosophie: Erstes Handbuch zur praktischen Wirtschaftsphilosophie (pp. 1-13). Wiesbaden: Springer VS.

Glaser, C. (2017). Wettbewerbsfaktor Vertrieb bei Finanzdienstleistern: Ein ganzheitliches Konzept zur Sales Excellence. Wiesbaden: Springer Fachmedien Wiesbaden.

GLS Gemeinschaftsbank eG (2021). So wirkt grünes Geld. Retrieved from https://www.gls.de/privatkunden/wirkung/

Görgen, F. (2007). Versicherungsmarketing: Strategien, Instrumente und Controlling (2., aktualisierte und überarb. Aufl.). Stuttgart: Kohlhammer.

Gouthro, P. A. (2017). The promise of lifelong learning. International Journal of Lifelong Education, 36(1-2), 45-59. https://doi.org/10.1080/02601370.2017.1270067

Gütling, T. (2021, February 23). Untreue: Ex-Vorstand der Raiffeisenbank Emtmannsberg angeklagt. Retrieved from https://www.br.de/nachrichten/bayern/raiffeisenbankemtmannsberg-untreue-ex-vorstand-wegen-veruntreuung-angeklagt,SPpNOSR

Handwerkskammer zu Leipzig (2017). Studie: Deutsche vertrauen dem Handwerk. Retrieved from https://www.hwk-leipzig.de/artikel/studie-deutsche-vertrauen-dem-handwerk3,0,7718.html

Hartmann, K. (2014). Zu ethischen Standards im Versicherungsvertrieb (Bachelor-Thesis). Hochschule Mittweida University of applied science, Mittweida.

Hartung, T. (2020). Versicherungsunternehmen. In L. Gramlich, P. Gluchowski, K. Schäfer, \& G. Waschbuch (Eds.), Gabler Banklexikon. Wiesbaden: SpringerGabler. Retrieved from https://www.gabler-banklexikon.de/definition/versicherungsunternehmen62326/version-375818 
Heegardt, C., \& Kreye, T. (2020). Sachkundenachweis und Erlaubnispflicht für erlaubnispflichtige Vermittler der Finanzbranche. Retrieved from https://www.hannover.ihk.de/rechtsteuern/recht8/themengebiete$\mathrm{recht} / \mathrm{recht} 1 / 1 \mathrm{x} 1$ desgewerberechts/erlaubnis-sachkunde.html

Hellenkamp, D. (2018). Bankwirtschaft. Studienwissen kompakt. Wiesbaden: Springer Fachmedien Wiesbaden.

Hohenstein, J. (2020). Statistisches Taschenbuch der Versicherungswirtschaft 2020. Berlin.

Hollmann, D., Kunzlmann, J., \& Riess, B. (2020). Der Beitrag von Stiftungen zur Verbreitung und Verstetigung von Corporate Social Responsibility. In S. Genders (Ed.), Management-Reihe Corporate Social Responsibilitiy. CSR und Institutionen: Etablierung unternehmerischer Verantwortung in Wirtschaft, Politik und Gesellschaft (pp. 207-216). Berlin, Heidelberg: Springer Berlin Heidelberg.

Hoppe, U. (2000). Teachware für Finanzdienstleister: Entwicklung - Integration - Einsatz. Wiesbaden: Deutscher Universitätsverlag.

Hößlinger, G. (1930). Versicherung und Ethik. Die Versicherung, 48(5), 3-19.

HRK Hochschulrektorenkonferenz (2020). Statistische Daten zu Studienangeboten an Hochschulen in Deutschland: Studiengänge, Studierende, Absolventinnen und Absolventen. Wintersemester 2020/2021. Berlin.

Hufeld, F. (2019, May). "Finanzen und ethische Verantwortung": Impulsvortrag von Felix Hufeld, Präsident der BaFin, am 10. Mai 2019 bei der Frühjahrstagung 2019 „Responsible Finance“ in Köln. Frühjahrstagung 2019 "Responsible Finance", Köln. Retrieved from https://www.bafin.de/SharedDocs/Veroeffentlichungen/DE/Reden/re_190510_responsib le finance p.html

IHK München und Oberbayern (2021). Versicherungsvermittler/in und -berater/in: Gewerbeerlaubnisse. Retrieved from https://www.ihkmuenchen.de/Versicherungsvermittler/

Iu Internationale Hochschule (2021). Daten \& Fakten. Retrieved from https://www.iubhuniversity.de/die-iubh/ueber-uns/

Izzo-Wagner, A., \& Siering, L. M. (2020). Kryptowährungen und geldwäscherechtliche Regulierung. Wiesbaden: Springer Fachmedien Wiesbaden.

Jäggi, C. J. (2016). Auf dem Weg zu einer inter-kontextuellen Ethik: Übergreifende Elemente aus religiösen und säkularen Ethiken. Ethik interdisziplinär: Band 23. Zürich: LIT.

Jäggi, C. J. (2018). Wirtschaftsordnung und Ethik: Problemfelder - Modelle - Lösungsansätze. Wiesbaden: Springer Fachmedien Wiesbaden.

Jarkovská, P. (2020). Corporate social responsibility as a motivation driver for employee performance. In Faculty of Economics, University of South Bohemia in České Budejovice (Ed.), Proceedings of the 13 th International Scientific Conference INPROFORUM: Innovations, Enterprises, Regions and Management (pp. 8-13). České Budějovice: Faculty of Economics, University of South Bohemia in České Budějovice.

Karlshaus, A., \& Segger, P. (2017). Führungskräfte in der Beschaffung. In E. Fröhlich \& A. Karlshaus (Eds.), Personalentwicklung in der Beschaffung: Best Practices aus Theorie und Praxis (pp. 91-117). Berlin, Heidelberg: Springer Berlin Heidelberg.

Karten, W., Nell, M., Richter, A., \& Schiller, J. (2018). Risiko und Versicherungstechnik: Eine ökonomische Einführung. Wiesbaden: Springer Fachmedien Wiesbaden.

Kašparová, L., \& Vejsadová Dryjová, M. (2021). Possibilities of using circular economy in a school contributory organization. In D. Škodová Parmová (Ed.), Regions in Context. Principles of circular economics in regional management leading to increased efficiency of systems: Regions in Context II (pp. 126-144). Budweis: Universitiy of South Bohemia. 
Kay-Enders, B. (2013). Marketing und Ethik: Grundlagen - Determinanten Handlungsempfehlungen (4th ed.). Wiesbaden, s.1.: Deutscher Universitätsverlag. Retrieved from http://dx.doi.org/10.1007/978-3-663-08722-9

Kisch, W. (1935). Die Ethik im Versicherungswesen. Zeitschrift für die gesamte Versicherungswirtschaft (ZVersWiss), 35, 277-291.

Klesper, M. Berufsbegleitendes Studium in Deutschland: Grundlegende Daten, Statistiken, \& Fakten. Retrieved from https://www.studieren-berufsbegleitend.de/infos/datenstatistik/\#daten-deutschland

Köhne, T., \& Melashenko, I. (2019). Produktinnovationen und Produktmodifikationen in der Versicherungswirtschaft zwischen 2006 und 2017. Zeitschrift für die gesamte Versicherungswirtschaft (ZVersWiss), 275-305. https://doi.org/10.1007/s12297-019-00449-6

König, M., \& Schmidt, M. (2002). Unternehmensethik konkret: Gesellschaftliche Verantwortung ernst gemeint. Wiesbaden: Gabler Verlag.

Krämer, A., \& Schmutz, I. (2020). Mythos Value-Based-Pricing: Der Versuch einer (wertfreien) Einordnung. Marketing Review St. Gallen. (2).

Krechovska, M., \& Hejdukova, P. n. (2019). Circular economy - concept and development of business models. In D. Škodová-Parmová \& Z. Dvořáková-Líšková (Eds.), Regions in context (1st ed., pp. 9-25). České Budějovice: University of South Bohemia, Faculty of Economics.

Küpper, H.-U. (2006). Unternehmensethik: Hintergründe, Konzepte, Anwendungsbereiche. Bremen: Schäffer-Poeschel Verlag für Wirtschaft Steuern Recht GmbH. Retrieved from http://gbv.eblib.com/patron/FullRecord.aspx?p=669256

Läsch-Weber, B. (2020). Unsere Sparkassen im Dienst der Bürgerinnen und Bürger. In M. Schmitz \& R. Schmidpeter (Eds.), CSR in Rheinland-Pfalz: Nachhaltige Entwicklung aus Sicht von Wirtschaft, Wissenschaft, Politik und Zivilgesellschaft (pp. 379-390). Berlin, Heidelberg: Springer Berlin Heidelberg.

Lenger, A., \& Kruse, J. (2017). Qualitative Forschungsmethoden in der deutschen Volkswirtschaftslehre.: Eine explorative Erhebung zugrunde liegender Repräsentationsmuster. In J. Maeße, H. Pahl, \& J. Sparsam (Eds.), Die Innenwelt der Ökonomie: Wissen, Macht und Performativität in der Wirtschaftswissenschaft (pp. 107134). Wiesbaden: Springer VS.

Loew, T., Ankele, K., Braun, S., \& Clausen, J. (2004). Bedeutung der internationalen CSRDiskussion für Nachhaltigkeit und die sich daraus ergebenden Anforderungen an Unternehmen mit Fokus Berichterstattung: Endbericht. Münster: Bundesministerium für Umwelt, Naturschutz und Reaktorsicherheit.

Lokuge, S., \& Subasinghage, M. (2020). Knowledge Management Competence and ISD Vendor Innovativeness in Turbulent Markets: Research-in-progress. In Association for Information Systems (Chair), ACIS 2020. Symposium conducted at the meeting of Association for Information Systems, Wellington, New Zealand.

Maisch, N., \& Schick, G. (2014). Positionspapier: Verbraucherpolitischer Neustart für die private Altersvorsorge!. Vierteljahrshefte zur Wirtschaftsforschung, 83(3), 101-111. https://doi.org/10.3790/vjh.83.3.101

Manzeschke, A., \& Brink, A. (2020). Ethik der Digitalisierung in der Finanzbranche am Beispiel der Finanzdienstleistungen. In W. Frenz (Ed.), Handbuch Industrie 4.0: Recht, Technik, Gesellschaft (pp. 1407-1414). Berlin, Heidelberg: Springer Berlin Heidelberg.

Marešová, P., Bureš, V., Štemberková, R., Matulová, P., Krejcar, O., Toman, J., \& Škodová Parmová, D. (2020a). Od Výzkumu po využívání v praxi: Vše kolem transferu znalostí a technologií. Hradec Králové: nakladatelství GAUDEAMUS. 
Marešová, P., Bureš, V., Štemberková, R., Matulová, P., Krejcar, O., Toman, J., \& Škodová Parmová, D. (2020b). Od výzkumu po využívání v praxi:: Vše kolem transferu znalostí a technologií. Hradec Králové: nakladatelství GAUDEAMUS.

Martin, J., Elg, M., Gremyr, I., \& Wallo, A. (2021). Towards a quality management competence framework: Exploring needed competencies in quality management. Total Quality Management \& Business Excellence, 32(3-4), 359-378. https://doi.org/10.1080/14783363.2019.1576516

Mast, C., Huck-Sandhu, S., \& Güller, K. (2005). Kundenkommunikation: Ein Leitfaden (1. Aufl.). UTB Betriebswirtschaftslehre, Kommunikationswissenschaft: Vol. 2492. Stuttgart: Lucius und Lucius. Retrieved from http://www.utb-studi-ebook.de/9783838524924

Mattgey, A. (2018). Deutsche Bank will ihr mieses Image mit dieser Kampagne loswerden: Globaler Auftritt. Werben und Verkaufen. (6). Retrieved from https://www.wuv.de/marketing/deutsche_bank_will_ihr_mieses_image_mit_dieser_kam pagne_loswerden

Messner, P. (2020). Es gibt keine einheitliche Definition von Nachhaltigkeit: Analystin zu grünen Investitionen. Retrieved from https://www.dasinvestment.com/analystin-zugruenen-investitionen-es-gibt-keine-einheitliche-definition-von-nachhaltigkeit/

Mey, G., \& Mruck, K. (Eds.) (2014). Qualitative Forschung: Analysen und Diskussionen - 10 Jahre Berliner Methodentreffen. Wiesbaden: Springer Fachmedien Wiesbaden.

Meyer, M. (2020). Liberaldemokratie: Wohlstand zwischen Freiheit und autokratischer Führung. Wiesbaden: Springer Fachmedien Wiesbaden.

Michael, C., \& Abraham, N. (2009). BERUFS- UND KARRIEREPLANER BANKEN 2009. Wiesbaden: Gabler Verlag / Springer Fachmedien Wiesbaden GmbH Wiesbaden. Retrieved from http://dx.doi.org/10.1007/978-3-8349-6301-7

Miebach, B. (2017). Handbuch Human Resource Management: Das Individuum und seine Potentiale für die Organisation. Wiesbaden: Springer Fachmedien Wiesbaden.

MLP SE (2020). MLP Nachhaltigkeitsbericht 2020: Entsprechenserklärung des Deutschen Nachhaltigkeitskodex. Wiesloch: MLP SE.

Möller, S. (2008). Gültigkeit der Charakteristika von Dienstleistungen - Eine Frage des Bezugsobjektes. In M. Benkenstein (Ed.), Gabler Edition Wissenschaft Focus Dienstleistungsmarketing. Neue Herausforderungen an das Dienstleistungsmarketing (pp. 197-215). Wiesbaden: Betriebswirtschaftlicher Verlag Dr. Th. Gabler / GWV Fachverlage GmbH Wiesbaden.

Moodley, T., \& Govender, K. (2020). Collaborative Leadership and Customer-Centricity: The Case of an Insurance Service Provider. Journal of Public Value and Administrative Insight, 3(3), 66-81. $\quad$ Retrieved from https://www.readersinsight.net/JPVAI/article/view/1487

Mulke, W. (2021). Nachhaltig Geld anlegen: Ökologisch, sozial und ethisch investieren (1. Auflage). Berlin: Stiftung Warentest.

Noll, B. (2013). Wirtschafts- und Unternehmensethik in der Marktwirtschaftt (2., aktualisierte und überarb. Aufl.). Stuttgart: Kohlhammer. Retrieved from http://gbv.eblib.com/patron/FullRecord.aspx?p=2060861

Nolte, P. (2021). Kompensation und Stabilisierung: Corona, der Staat und die Soziale Marktwirtschaft in Deutschland. List Forum für Wirtschafts- und Finanzpolitik, 22, 113. https://doi.org/10.1007/s41025-021-00215-6

Palm, T. (2012). Service Level in der Assekuranz: Ein Kommunikationsproblem? (1. Aufl.). s.l.: Diplomica Verlag GmbH. Retrieved from http://site.ebrary.com/lib/alltitles/docDetail.action?docID=10553055 
Park, C.-Y., \& Kim, J. (2020). Education, Skill Training, and Lifelong Learning in the Era of Technological Revolution. SSRN Electronic Journal, 96(3), 1043. https://doi.org/10.2139/ssrn.3590922

Pekruhl, U., Vogel, C., \& Strohm, O. (2018). Integriertes Personalmanagement in kleinen Unternehmen: Ein Praxisratgeber. Berlin, Heidelberg: Springer Berlin Heidelberg.

Petersen, T. (2017). Unternehmensethik und Verantwortung. In T. Petersen, J. H. Quandt, \& M. Schmidt (Eds.), Führung in Verantwortung: Ethische Aspekte für ein zeitgemäßes Management (pp. 25-40). Wiesbaden: Springer Fachmedien Wiesbaden.

Pietsch, D. (2019). Eine Reise durch die Ökonomie: Über Wohlstand, Digitalisierung und Gerechtigkeit. Wiesbaden: Springer Fachmedien Wiesbaden.

Poerschke, J. (2021). Ethik in der Abfallwirtschaft. In U. Breuer \& D. D. Genske (Eds.), Ethik in den Ingenieurwissenschaften: Eine Annäherung (pp. 321-344). Wiesbaden: Springer Fachmedien Wiesbaden.

Pridatt, B. (2018). Wirtschaftsphilosophie $=$ Wirtschaftsethik? Zeitschrift für Wirtschafts- und Unternehmensethik, 19(2), 172-192.

Priddat, B. (2020). Über notwendige Ausweitungen der Pluralen Ökonomie. In C. Fridrich, R. Hedtke, \& W. O. Ötsch (Eds.), Grenzen überschreiten, Pluralismus wagen Perspektiven sozioökonomischer Hochschullehre (pp. 11-24). Wiesbaden: Springer Fachmedien Wiesbaden.

Priddat, B. P. (2015). Moralproduktion durch Märkte: Moral ohne Ethik. In I. Pies (Ed.), Angewandte Ethik Marktwirtschaft und Moral: Band 1. Der Markt und seine moralischen Grundlagen: Diskussionsmaterial zu einem Aufsatz von Jeff R. Clark und Dwight R. Lee (pp. 161-168). Freiburg, München: Verlag Karl Alber.

Priddat, B. P. (2010). Wozu Wirtschaftsethik? (1. Aufl.). Ethik und Ökonomie: Vol. 12. Marburg: Metropolis-Verlag.

Provinzial Rheinland (2021). Werden Sie Teil einer erfolgreichen Zusammenarbeit als Vertriebsleiter/in oder Vertriebsspezialist/in bei der Provinzial Rheinland. Retrieved from https://www.provinzial.com/content/provinzial/karriere/vertrieb/vertriebsleiter/

Raatzsch, R. (2014). Ethik und Betriebswirtschaftslehre. In R. Raatzsch (Ed.), Ehrbare Kaufleute (pp. 87-91). Wiesbaden: Springer Fachmedien Wiesbaden. https://doi.org/10.1007/978-3-658-04424-4_7

Raith, F. (2020). Berücksichtigung ethischer Normen und Werte im Marketing: Auswirkungsanalyse auf den Unternehmenserfolg anhand von Fallstudien und Ableitung von Handlungsempfehlungen (Bachelor Thesis). Technische Hochschule Ingolstadt, Ingolstadt.

Rasch, D., Kubinger, K. D., \& Moder, K. (2011). The two-sample t test: Pre-testing its assumptions does not pay off. Statistical Papers, 52(1), 219-231. https://doi.org/10.1007/s00362-009-0224-x

Rathgeber, C., Edeling, S., \& Pilz, M. (2019). Christian Ebner / Sabrina Edeling / Matthias Pilz. Pädagogische Rundschau, 73.(4), 375-390. https://doi.org/10.3726/PR042019.0035

Reifner, U. (2017). Das Geld: Ökonomie des Geldes - Kooperation und Akkumulation (Vol. 1). Wiesbaden: Springer Fachmedien Wiesbaden.

Reisenauer, T. M. (2010). Unternehmensführung in der Wirtschaftskrise unter Berücksichtigung ethischer und moralischer Grundgedanken: Diplomarbeit. Diplomarbeit. Hamburg: Diplom.de. Retrieved from http://www.diplom.de

Revelle, W. (2020). psych: Procedures for Personality and Psychological Research (Version 2.0.9) [Computer software]. Evanston, Illinois: Northwestern University. Retrieved from https://CRAN.R-project.org/package=psych 
Rhein, S. (2017). Stakeholder-Dialoge für unternehmerische Nachhaltigkeit: Eine qualitativempirische Studie zum Diskursverhalten von Unternehmen. Mit einem Geleitwort von Dr. Stefan Hielscher und Prof. Dr. Ingo Pies. Wiesbaden: Springer Fachmedien Wiesbaden.

Richter, M., \& Steen, L. (2019). Corporate Social Responsibility (CSR): Konstruktiv-kritische Analyse für den Gesundheitsbereich. In W. Zapp (Ed.), Controlling im Krankenhaus: Das Zusammenspiel von Werten, Prozessen und Innovationen (pp. 67-94). Wiesbaden: Springer Fachmedien Wiesbaden.

Riege, J. (1990). Das Versicherungsprodukt. Zeitschrift für die gesamte $\begin{array}{lll}\text { Versicherungswirtschaft } \quad \text { (ZVersWiss), } & \text { 49(3), }\end{array}$ https://doi.org/10.1007/BF03188011

Rommerskirchen, J., \& Woll, A.-K. (2015). Normative Erwartungen und internalisierte Werte-Marken als ethische Konstrukte. Journal of Business and Media Psychology, $6(1), 10-25$.

Roth, W. (2021). Geprüfte/-r Fachwirt/Fachwirtin für Versicherungen und Finanzen. Retrieved from https://www.bwv.de/qualifikationen/fachwirt-fuer-versicherungen-undfinanzen/

Rybakova, A., Vinogradova, M., \& Sizikova, V. (2019). Advancing Leadership Careers with Leadership Competences. In W. Strielkowski (Ed.): Advancees in Social Science, Education and Humanities Research, Proceedings of the 5th International Conference on Social, Economic, and Academic Leadership (ICSEALV 2019) (pp. 1-6). Paris, France: Atlantis Press. https://doi.org/10.2991/assehr.k.191221.181

Schloz, B. (2020). Künstliche Intelligenz im Finanzdienstleistungssektor: Evaluierung des Meinungsbildes von Privatkunden zu Robo-Advice. Transferbeiträge zu innovativen Technologien: Band 5. Essen: MA Akademie Verlags- und Druckgesellschaft mbH.

Schmidt, P. (2019). Lohnt es sich heute noch Versicherungsmakler zu werden? Versicherungsbote. (5). Retrieved from https://www.versicherungsbote.de/id/4880159/Kommentar-VersicherungsmaklerZukunft/

Schmitz, M. (2017). Rollenkonflikte und Stress in hoch kompetitiven Systemen als Coachingthema. Organisationsberatung, Supervision, Coaching, 24(3), 323-332. https://doi.org/10.1007/s11613-017-0515-3

Schmola, G. (2015). Corporate Social Responsibility (CSR) in Krankenhäusern: Ist die DIN ISO 26000 eine geeignete Orientierungshilfe für die Erarbeitung eines CSR-Konzepts in Krankenhäusern? das Krankenhaus, 107(11), 1019-1022.

Schneider, W. (2020). Marketing-Ethik: Historische Entwicklung, Dimensionen, Strategien, Fallbeispiele. Fachbuchreihe "WiWi Kompetenz kompakt: Band 18. Norderstedt: BoD Books on Demand.

Schütt, A., \& Schulte, S. (2020). Cooperative Social Responsibility - der genossenschaftliche Förderauftrag im Licht der Diskussium um Unternehmensverantwortung. In S. Genders (Ed.), Management-Reihe Corporate Social Responsibilitiy. CSR und Institutionen: Etablierung unternehmerischer Verantwortung in Wirtschaft, Politik und Gesellschaft (pp. 193-206). Berlin, Heidelberg: Springer Berlin Heidelberg.

Sennewald, D. (2017). Ginmon: Robo Advisor. In V. Tiberius \& C. Rasche (Eds.), Edition BANKMAGAZIN. FinTechs: Disruptive Geschäftsmodelle (pp. 111-118). Wiesbaden: Springer Fachmedien Wiesbaden.

SIGNAL IDUNA. Verkaufsleiter (m/w/d). Retrieved from https://jobs.signaliduna.de/SIGNALIDUNA/job/Region-Ahaus-Gronau-Rheine/647234101/

SIGNAL IDUNA (Ed.) (2019). Compliance-Kodex der SIGNAL IDUNA Gruppe - finden Sie den richtigen Weg. Dortmund: SIGNAL IDUNA. 
Škodová Parmová, D., Líšková, Z., \& Kain, R. (2018). Cross-border regions as supporting structures for raising competitiveness in Europe. In Association of Economists and Managers of the Balkans (Ed.), Fourth international scientific conference ERAZ 2018: Knowledge based sustainable economic development (pp. 65-78). Sofia.

Škodová Parmová, D., Líšková, Z., Sdrolias, L., \& Kain, R. (2017). Systematic approaches and development strategies of the rural small and medium-sized firms in boarder regions. In P. Janecek (Ed.), Opportunities and threats to current business management in cross-border comparison 2017 (pp. 147-155). Lobnitz: Verlag GUC - Gesellschaft Unternehmensrechnung Controlling $\mathrm{mbH}$.

Škodová Parmová, D. (Ed.) (2021). Principles of circular economics in regional management leading to increased efficiency of systems: Regions in Context II. Regions in Context. Budweis: Universitiy of South Bohemia.

Slone, R., Dittmann, P. J., \& Mentzer, J. T. (2014). The New Supply Chain Agenda: The 5 Steps That Drive Real Value. Boston: Harvard Business Review Press. Retrieved from https://ebookcentral.proquest.com/lib/gbv/detail.action?docID $=5181518$

Smith, N. C., \& Murphy, P. E. (2012). Marketing ethics. Sage library in marketing. Los Angeles, Calif.: SAGE.

Sotz-Hollinger, G. (2009). Karriereerwartungen berufsbegleitend Studierender. Zeitschrift für Hochschulentwicklung, 4(2), 10-22.

Spiegel, A.-L. (2020). Change Management. In M. Oldhafer, F. Nolte, A.-L. Spiegel, \& U. Schrabback (Eds.), Arbeitsbuch zu Change Management in Gesundheitsunternehmen: Wellenbrecher des Wandels - praktische Übungen und Werkzeuge (pp. 15-24). Wiesbaden: Springer Fachmedien Wiesbaden.

Stiftung Warentest (2021). Nachhaltige Fonds mit Bestnoten: Ethisch-ökologische Fonds und ETF. Retrieved from https://www.test.de/Ethisch-oekologische-Fonds-So-legen-Siesauber-an-4741500-0/

Tenscher, J. (2003). Professionalisierung der Politikvermittlung? Politikvermittlungsexperten im Spannungsfeld von Politik und Massenmedien. Wiesbaden: VS Verlag für Sozialwissenschaften. Retrieved from http://dx.doi.org/10.1007/978-3-322-80484-6

Thakor, A. V. (2020). Fintech and banking: What we know? Journal of Financial Intermediation, 41(2), 100833. https://doi.org/10.1016/j.jfi.2019.100833

Thummes, K. (2019). CSR-Kommunikation von Unternehmen: Grundlagen der Verantwortungskommunikation. In A. Zerfaß, M. Piwinger, \& U. Röttger (Eds.), Springer Reference Wirtschaft. Handbuch Unternehmenskommunikation: Strategie Management - Wertschöpfung (3rd ed., pp. 1-16). Wiesbaden: Springer Fachmedien Wiesbaden GmbH; Springer Gabler.

Union Investment Privatfonds GmbH (2021). Welche Investmentfonds gibt es? Retrieved from https://www.union-investment.de/startseite/fonds_depot/fonds_verstehen

Versicherungsmagazin.de (2019). GDV gegen überbordende Regulierung. Versicherungsmagazin. (8). Retrieved from https://www.versicherungsmagazin.de/rubriken/branche/gdv-gegen-ueberbordenderegulierung-2447858.html

Vlčková, M., \& Jakubcová, B. (2019). Controlling in companies affected by the circular economy. In D. Škodová-Parmová \& Z. Dvořáková-Líšková (Eds.), Regions in context (1st ed., pp. 81-95). České Budějovice: University of South Bohemia, Faculty of Economics.

Von Münch, M. (2020). Forward ever, backward never. In A. Ternès von Hattburg \& J. Reiber (Eds.), Gründen mit Erfolg: Das eigene Startup-Unternehmen (1st ed., pp. 117124). Wiesbaden: SpringerGabler. 
Vrchota, J., \& Řehoř, P. (2019). The influence of a human resource strategy to the function of human resource processes in small and medium-sized enterprises (SMEs). Serbian Journal of Management, 14(2), 299-314.

W\&V Redaktion (2019). OWM: Werbeausgaben stagnieren: OWM-Umfrage 2019. Werben und Verkaufen. (11). Retrieved from https://www.wuv.de/marketing/owm_werbeausgaben_stagnieren

Wagner, B. (2017). Gesellschaftliche Verantwortung der Finanzwirtschaft. In G. Krämer (Ed.), Finanzwirtschaft in ethischer Verantwortung: Erfolgskonzepte für Social Banking und Social Finance (pp. 1-26). Wiesbaden: Springer Fachmedien Wiesbaden.

Warnes, G., Bolker, B., Bonebakker, L., Gentleman, R., Huber, W., Liaw, A., . . . Venables, B. (2020). gplots: Various R Programming Tools for Plotting Data (Version 3.1.1) [Computer software]. Retrieved from https://CRAN.R-project.org/package=gplots

Wewer, G. (2020). Digitale Agenda der Europäischen Kommission. In T. Klenk, F. Nullmeier, \& G. Wewer (Eds.), Handbuch Digitalisierung in Staat und Verwaltung: mit 22 Abbildungen und 12 Tabellen (pp. 373-383). Wiesbaden: Springer Fachmedien Wiesbaden.

Wickham, H. (2016). ggplot2: Elegant graphics for data analysis. Use R! New York: Springer Verlag. Retrieved from http://dx.doi.org/10.1007/978-3-319-24277-4

Wickham, H., \& Bryan, J. (2019). readxl: Read Excel Files (Version 1.3.1) [Computer software]. Retrieved from https://CRAN.R-project.org/package=readxl

Wieland, J. (2004). Die Ethik der Governance (3., unveränd. Aufl.). Institutionelle und evolutorische Ökonomik: Vol. 9. Marburg: Metropolis-Verl.

Yao, T., Qiu, Q., \& Wei, Y. (2019). Retaining hotel employees as internal customers: Effect of organizational commitment on attitudinal and behavioral loyalty of employees. International Journal of Hospitality Management, 76(5), 1-8. https://doi.org/10.1016/j.ijhm.2018.03.018

Youn, H., Lee, K., \& Lee, S. (2018). Effects of corporate social responsibility on employees in the casino industry. Tourism Management, 68(4), 328-335. https://doi.org/10.1016/j.tourman.2018.03.018

ZEIT Campus (2021). Hochschulen in Deutschland. Retrieved from https://studiengaenge.zeit.de/hochschulen/land/deutschland?wt_ref $=$ https $\% 3 \mathrm{~A} \% 2 \mathrm{~F} \% 2 \mathrm{~F}$ www.google.com\%2F\&wt time $=1616946272208$ 